\title{
New Cembranoids and a Biscembranoid Peroxide from the Soft Coral Sarcophyton cherbonnieri
}

\author{
Chia-Chi Peng ${ }^{1}$, Chiung-Yao Huang ${ }^{1}$, Atallah F. Ahmed ${ }^{2,3}$ (D), Tsong-Long Hwang 4,5,6 (D), \\ Chang-Feng Dai ${ }^{7}$ and Jyh-Horng Sheu 1,8,9,* \\ 1 Department of Marine Biotechnology and Resources, National Sun Yat-sen University, Kaohsiung 804, \\ Taiwan; m045020008@student.nsysu.edu.tw (C.-C.P.); huangcy@mail.nsysu.edu.tw (C.-Y.H.) \\ 2 Department of Pharmacognosy, College of Pharmacy, King Saud University, Riyadh 11451, Saudi Arabia; \\ afahmed@ksu.edu.sa \\ 3 Department of Pharmacognosy, Faculty of Pharmacy, Mansoura University, Mansoura 35516, Egypt \\ 4 Graduate Institute of Natural Products, College of Medicine, Chang Gung University, Taoyuan 333, Taiwan; \\ htl@mail.cgu.edu.tw \\ 5 Research Center for Industry of Human Ecology and Graduate Institute of Health Industry Technology, \\ Chang Gung University of Science and Technology, Taoyuan 333, Taiwan \\ 6 Department of Anesthesiology, Chang Gung Memorial Hospital, Taoyuan 333, Taiwan \\ 7 Institute of Oceanography, National Taiwan University, Taipei 112, Taiwan; corallab@ntu.edu.tw \\ 8 Graduate Institute of Natural Products, Kaohsiung Medical University, Kaohsiung 807, Taiwan \\ 9 Frontier Center for Ocean Science and Technology, National Sun Yat-sen University, Kaohsiung 804, Taiwan \\ * Correspondence: sheu@mail.nsysu.edu.tw; Tel.: +886-7-525-2000 (ext. 5030); Fax: +886-7-525-5020
}

Received: 27 June 2018; Accepted: 31 July 2018; Published: 6 August 2018

\begin{abstract}
Six new cembranoids, cherbonolides A-E (1-5) and bischerbolide peroxide (6), along with one known cembranoid, isosarcophine (7), were isolated from the Formosan soft coral Sarcophyton cherbonnieri. The structures of these compounds were elucidated by detailed spectroscopic analysis and chemical methods. Compound $\mathbf{6}$ was discovered to be the first example of a molecular skeleton formed from two cembranoids connected by a peroxide group. Compounds 1-7 were shown to have the ability of inhibiting the production of superoxide anions and elastase release in $N$-formyl-methionyl-leucyl-phenylalanine/cytochalasin B (fMLF/CB)-induced human neutrophils.
\end{abstract}

Keywords: Sarcophyton cherbonnieri; cembranoid; biscembranoid peroxide; anti-inflammatory activity; elastase release inhibition

\section{Introduction}

Many cembrane-based natural products have been shown to exhibit significant activities such as cytotoxicity [1-14] and anti-inflammatory activity [9,11,13-18]. From the experience of searching bioactive metabolites from soft corals, series of cembranoids have been unveiled from octocorals (Alcyonaceae) belonging to the genera Sarcophyton, $[1-8,16]$, Sinularia $[9-12,17,18]$ and Lobophyton [13-15]. Also, previous studies showed that two cembranoid units could form biscembranoid-type compounds by Diels-Alder reaction [19-21], radical dimerization [22,23], or connection with a sulfur atom [18], making the chemistry of cembranes more complex and interesting than monomeric form.

Our current chemical investigation on Sarcophyton cherbonnieri led to the discovery of six new cembranoids, cherbonolides A-E (1-5) and bischerbolide peroxide (6), and one known compound, isosarcophine (7) [24]. The structures of 1-7 (Figure 1) were elucidated by extensive spectroscopic analysis, including detailed 2D nuclear magnetic resonance (NMR) experiments and chemical methods. Compounds 2, 5, and $\mathbf{6}$ were characterized as cembranoids bearing an allylic peroxyl group as those 
previously discovered marine cembranoidal peroxides [25-29]. Furthermore, compound 6 is the first example of a biscembranoid with two cembranoidal units interconnected by a peroxyl group. The absolute configurations of $\mathbf{1}$ and $\mathbf{3}$ were further established using a modified Mosher's reaction. Also, evaluation of the in vitro anti-inflammatory activities through the inhibition of superoxide anion $\left(\mathrm{O}_{2}{ }^{\bullet}\right)$ generation and elastase release in $\mathrm{N}$-formyl-methionyl-leucyl-phenylalanine/cytochalasin B (fMLF/CB)-induced human neutrophils was carried out.

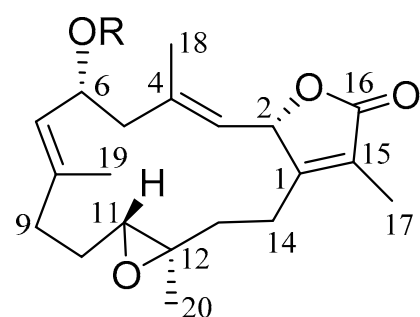

$1: \mathrm{R}=\mathrm{H}$

2: $\mathrm{R}=\mathrm{OH}$

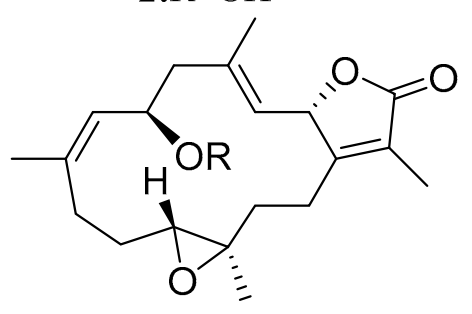

$4: \mathrm{R}=\mathrm{H}$

5: $\mathrm{R}=\mathrm{OH}$

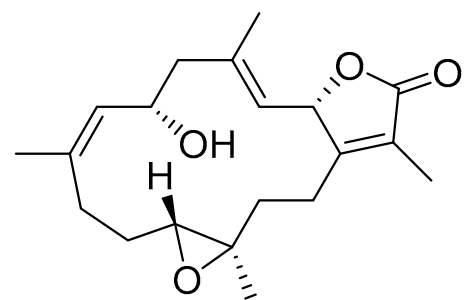

3<smiles>CC/C=C\CCC(C)=C[C@@H]1OC(=O)C(C)=C1CC[C@@H]1O[C@H]1C</smiles>

7

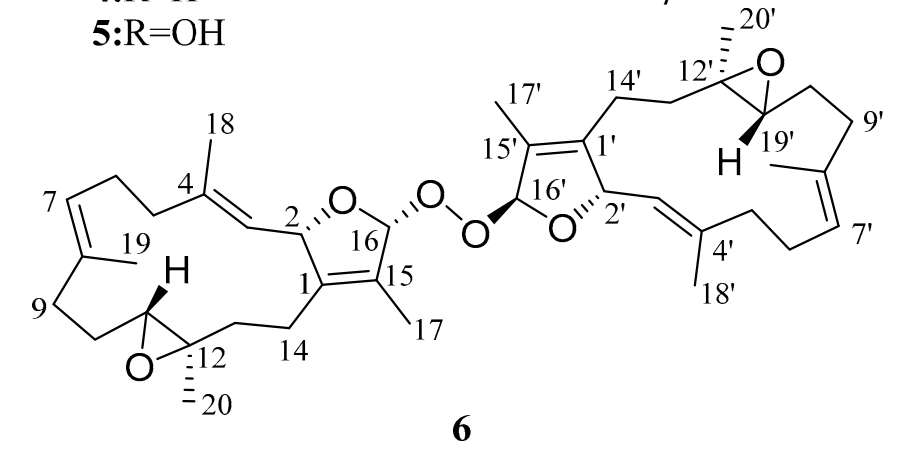

Figure 1. Cembranoid isolated from Sarcophyton cherbonnieri.

\section{Results and Discussion}

The soft coral S. cherbonnieri (1.2 kg, wet weight) was collected using SCUBA diving from Jihui Port of Taitung, Taiwan, in March 2013, and stored in a freezer before extraction. The freeze-dried organisms (207 g) were sliced into small pieces, followed by exhaustive extraction with ethyl acetate (EtOAc). The EtOAc extract was dried with anhydrous sodium sulfate $\left(\mathrm{Na}_{2} \mathrm{SO}_{4}\right)$. After removal of EtOAc under reduced pressure, the residue yielded was separated by silica gel column chromatography and the resolved fractions were further purified by reverse-phase $C_{18}$ high-performance liquid chromatography (HPLC) to afford compounds 1-7 (Figure 1), the structures of which were elucidated on the basis of spectroscopic analyses (Supplementary Materials, Figures S1-S46).

Cherbonolide A (1) was isolated as a colorless oil. The molecular formula $\mathrm{C}_{20} \mathrm{H}_{28} \mathrm{O}_{4}$ of $\mathbf{1}$ was determined by the high-resolution electrospray ionization mass spectrometry (HRESIMS) $(\mathrm{m} / z$ calcd 355.1880; found 355.1879, $\left.[\mathrm{M}+\mathrm{Na}]^{+}\right)$, which required seven degrees of unsaturation. The IR spectrum of 1 showed the presence of a hydroxyl group $\left(v_{\max } 3457 \mathrm{~cm}^{-1}\right)$ and a lactonic carbonyl group $\left(v_{\max }\right.$ $1746 \mathrm{~cm}^{-1}$ ). The presence of 20 carbons in the structure of 1 , including four methyls, five $s p^{3}$ methylenes, three $s p^{3}$ oxygenated methines, two $s p^{2}$ methines, one $s p^{3}$ and five $s p^{2}$ nonprotoned carbon atoms were 
assigned with the aid of distortionless enhancement by polarization transfer (DEPT) spectra. The NMR peaks resonating at $\delta_{\mathrm{C}} 174.4(\mathrm{C}), 160.7(\mathrm{C}), 123.8(\mathrm{C}), 77.8(\mathrm{CH})$ and $8.8\left(\mathrm{CH}_{3}\right)$, and $\delta_{\mathrm{H}} 5.44(1 \mathrm{H}$, dd, $J=10.0,1.6 \mathrm{~Hz})$ and $\delta_{\mathrm{H}} 1.86(3 \mathrm{H}, \mathrm{s})$, are characteristic signals of an $\alpha$-methyl- $\alpha, \beta$-unsaturated- $\gamma$-lactone ring by comparison of the NMR data of the $\gamma$-lactone ring of known compound isosarcophine (7). Signals at $\delta_{\mathrm{C}} 60.8(\mathrm{C}), 61.4(\mathrm{CH})$ and $\delta_{\mathrm{H}} 2.42(1 \mathrm{H}, \mathrm{dd}, J=10.8,2.8 \mathrm{~Hz})$ showed the presence of a trisubstituted epoxide. Two trisubstituted double bonds could also be identified by NMR signals resonating at $\delta_{\mathrm{C}} 122.2(\mathrm{CH}), \delta_{\mathrm{C}} 141.6(\mathrm{C})$ and $\delta_{\mathrm{H}} 4.90(1 \mathrm{H}, \mathrm{d}, J=10.0 \mathrm{~Hz})$, and at $\delta_{\mathrm{C}} 128.1(\mathrm{CH}), \delta_{\mathrm{C}}$ $139.8(\mathrm{C})$ and $\delta_{\mathrm{H}} 5.20(1 \mathrm{H}, \mathrm{d}, J=10.4 \mathrm{~Hz})$, respectively. The correlations identified from the ${ }^{1} \mathrm{H}-{ }^{1} \mathrm{H}$ correlation spectroscopy $\left({ }^{1} \mathrm{H}_{-}{ }^{1} \mathrm{H}\right.$ COSY $)$ spectrum revealed four separate proton sequences, as shown in Figure 2, which were assembled by heteronuclear multiple bond correlation (HMBC) correlations (Figure 2). Key HMBC correlations of H-2 $\left(\delta_{\mathrm{H}} 5.44,1 \mathrm{H}, \mathrm{dd}, J=10.0,1.6 \mathrm{~Hz}\right)$ to C-1; $\mathrm{H}_{2}-14\left(\delta_{\mathrm{H}} 2.01\right.$, $\mathrm{m}) / \mathrm{C}-1 ; \mathrm{H}_{3}-17\left(\delta_{\mathrm{H}} 1.86\right.$, s) to C-1, C-15 and C- $16 ; \mathrm{H}_{3}-18\left(\delta_{\mathrm{H}} 1.70\right.$, s) to C-3, C-4 and C-5; $\mathrm{H}_{3}-19\left(\delta_{\mathrm{H}} 1.86\right.$, s) to $\mathrm{C}-7, \mathrm{C}-8$ and $\mathrm{C}-9$; and $\mathrm{H}_{3}-20\left(\delta_{\mathrm{H}} 1.33\right.$, s) to $\mathrm{C}-11, \mathrm{C}-12$ and $\mathrm{C}-13$, established the connection of the four proton sequences, and thus constructed the 14-membered ring carbon skeleton, which also indicated the presence of a hydroxyl at C-6. Thus, the planar structure of $\mathbf{1}$ was established.

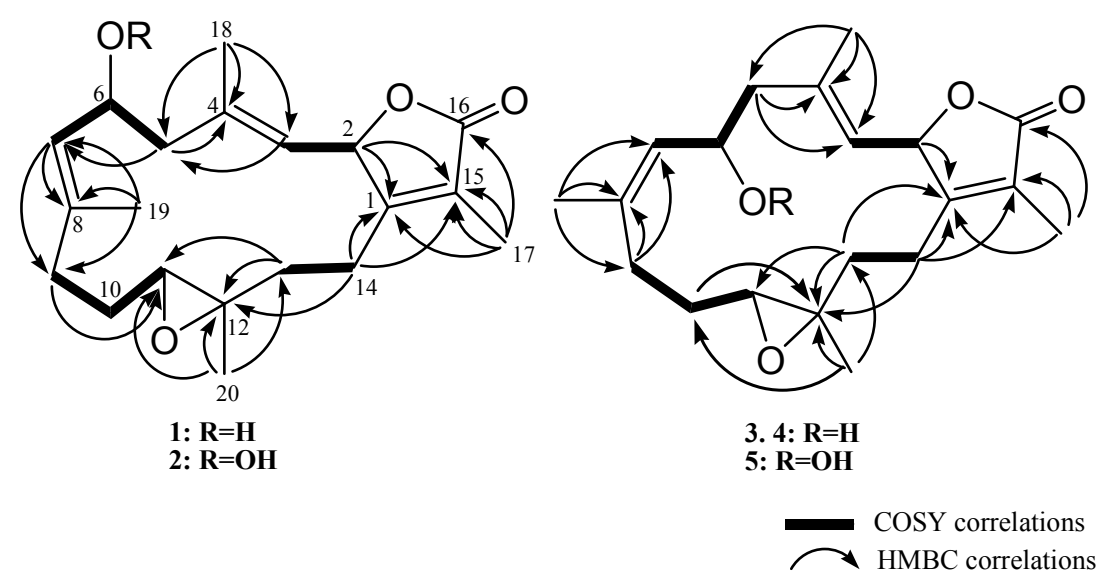

Figure 2. Selected ${ }^{1} \mathrm{H}-{ }^{1} \mathrm{H}$ COSY and $\mathrm{HMBC}$ correlations of 1, 2 and $\mathbf{3 - 5 .}$

Further, careful analysis of nuclear Overhauser enhancement (NOE) correlations was applied to establish the relative stereochemistry of $\mathbf{1}$, as shown in Figure 3. The NOE spectrum revealed that $\mathrm{H}-2$ $\left(\delta_{\mathrm{H}} 5.44, \mathrm{dd}, J=10.0,1.6 \mathrm{~Hz}\right)$ showed $\mathrm{NOE}$ correction with $\mathrm{H}_{3}-18\left(\delta_{\mathrm{H}} 1.70, \mathrm{~s}\right)$; therefore, assuming a $\beta$-orientation of $\mathrm{H}-2, \mathrm{H}_{3}-18$ should be $\beta$-oriented, too. Moreover, $\mathrm{H}_{3}-18$ exhibited $\mathrm{NOE}$ correlation with $\mathrm{H}-6\left(\delta_{\mathrm{H}} 4.70, \mathrm{ddd}, J=10.4,10.4,5.2 \mathrm{~Hz}\right)$, revealing the $\beta$-orientation of $\mathrm{H}-6$ and the $R^{*}$ configuration of C-6. One methylene proton at $\mathrm{C}-13$ exhibited NOE correlation with $\mathrm{H}-2$ and was characterized as $\mathrm{H}-13 \beta$ $\left(\delta_{\mathrm{H}} 1.06, \mathrm{~m}\right)$, while the other proton was assigned as $\mathrm{H}-13 \alpha\left(\delta_{\mathrm{H}} 2.03, \mathrm{~m}\right)$. NOE correlations of $\mathrm{H}-13 \beta$ with $\mathrm{H}-11\left(\delta_{\mathrm{H}} 2.42, \mathrm{dd}, J=10.8,2.8 \mathrm{~Hz}\right)$ and $\mathrm{H}-13 \alpha$ with $\mathrm{H}_{3}-20\left(\delta_{\mathrm{H}} 1.33, \mathrm{~s}\right)$ reflected the $\beta$-orientation of $\mathrm{H}-11$ and the $\alpha$-orientation of $\mathrm{H}_{3}-20$, and hence the $R^{*}$ configurations of both $\mathrm{C}-11$ and $\mathrm{C}-12$. The $E$ geometries of the trisubstituted C-3/C-4 and C-7/C-8 double bonds were also assigned from the NOE correlations of $\mathrm{H}_{3}-18\left(\delta_{\mathrm{H}} 1.70\right.$, s) with $\mathrm{H}-2$, but not with $\mathrm{H}-3\left(\delta_{\mathrm{H}} 4.90, \mathrm{~d}, J=10.0 \mathrm{~Hz}\right)$, as well as $\mathrm{H}_{3}-19$ $\left(\delta_{\mathrm{H}} 1.86, \mathrm{~s}\right)$ with $\mathrm{H}-6$, but not with $\mathrm{H}-7\left(\delta_{\mathrm{H}} 5.20, \mathrm{~d}, J=10.4 \mathrm{~Hz}\right)$, and were also confirmed by the upfield chemical shifts $\left(\delta_{C}<20 \mathrm{ppm}\right)$ observed for both $C-18\left(\delta_{C} 15.9\right)$ and $C-19\left(\delta_{C} 14.9\right)$ [30]. Based on the above observations and the detailed analysis of other NOE correlations, the relative configuration of this compound was established. Furthermore, the absolute configuration of $\mathbf{1}$ at C-6 was determined by the modified Mosher's esterification method [31,32]. The (S)- and $(R)$-MTPA esters of $\mathbf{1}(\mathbf{1} \mathbf{a}$ and $\mathbf{1 b}$, respectively, as shown in Figure 4) were afforded by the reaction of 1 with $(R)-(-)$ and $(S)-(+)-M T P A$ chloride, respectively. Determination of the $\Delta \delta$ values $\left(\delta_{S}-\delta_{R}\right)$ for protons nearing C-6 resulted in the establishment of the $R$ configuration at C-6 in $\mathbf{1}$ (Figure 4). The absolute configuration of $\mathbf{1}$ was 
thus assigned as $2 S, 6 R, 11 R, 12 R$, mostly the same as that of isosarcophine (7) [24], except that of C-6. Therefore, cherbonolide A (1) was identified as 6- $\alpha$-hydroxyisosarcophine.

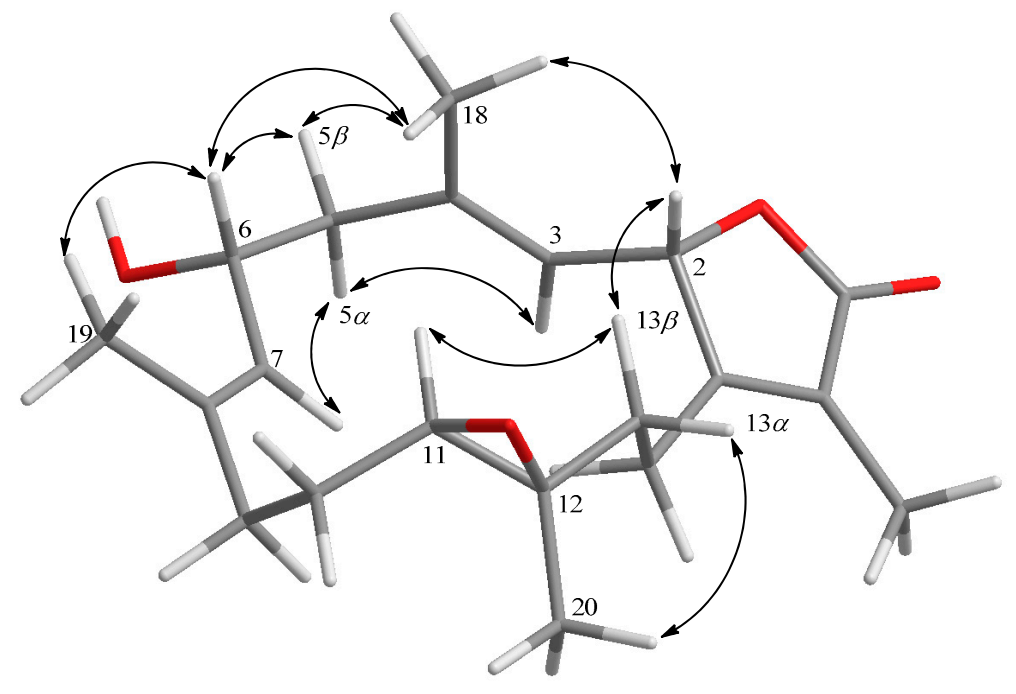

Figure 3. Key NOESY correlations of $\mathbf{1}$.
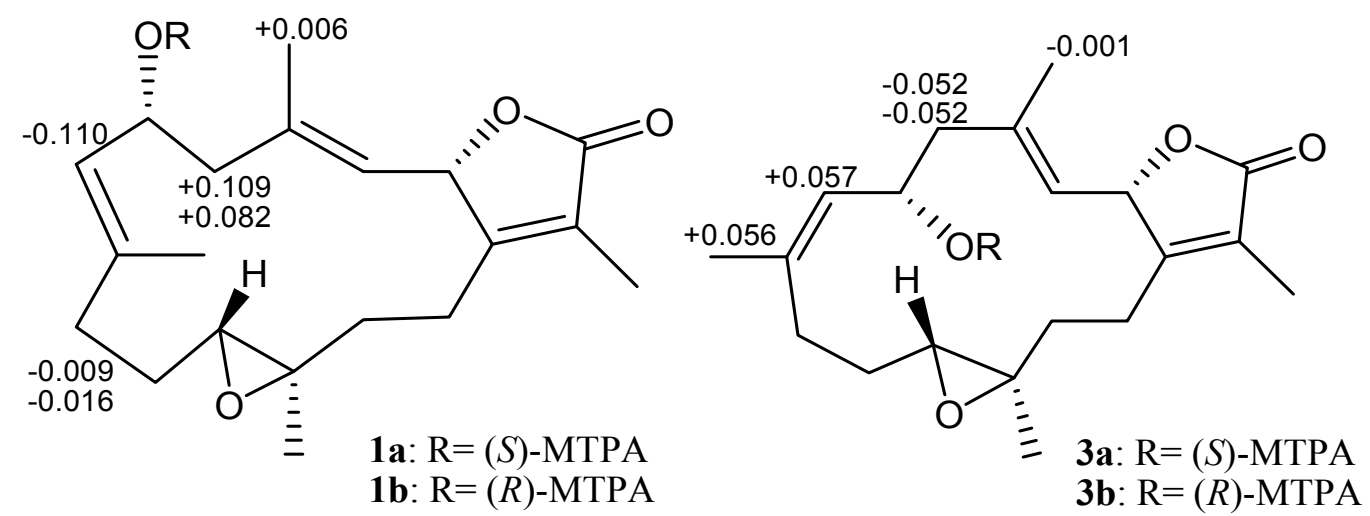

Figure 4. ${ }^{1} \mathrm{H}$ NMR chemical shift differences $\Delta \delta\left(\delta_{S}-\delta_{R}\right)$ in ppm for the MTPA esters of 1 and 3.

The molecular formula of cherbonolide $\mathrm{B}$ (2) was determined to be $\mathrm{C}_{20} \mathrm{H}_{28} \mathrm{O}_{5}$ by the HRESIMS $\left(\mathrm{m} / z\right.$ calcd 371.1830; found 371.1829, $\left.[\mathrm{M}+\mathrm{Na}]^{+}\right)$, having one more oxygen than 1 . Moreover, both $\mathbf{1}$ and 2 had almost identical ${ }^{1} \mathrm{H}$ and ${ }^{13} \mathrm{C}$ NMR data (Table 1), except for those of $\mathrm{C}-6$. The allylic hydroxy group of $\mathbf{1}$ at C-6 was substituted by a hydroperoxyl in 2, with the characteristic signal of a broad singlet in the downfield region, $\delta_{\mathrm{H}} 7.99[26,33,34]$. Obvious downfield shifts of $C-6\left(\delta_{C} 65.2\right.$ in $1,78.3$ in 2) and $\mathrm{H}-6\left(\delta_{\mathrm{H}} 4.70\right.$ in 1, 4.97 in 2) were also observed, indicating that 2 possesses the hydroperoxy group at C-6. Furthermore, reduction of 2 by reaction with triphenylphosphine afforded 1 . On the basis of the above analyses, the planar structure and the $(2 S, 6 R, 11 R, 12 R)$-configuration of 2 were determined. 
Table 1. ${ }^{1} \mathrm{H}$ and ${ }^{13} \mathrm{C}$ NMR chemical shifts for compounds 1-4.

\begin{tabular}{|c|c|c|c|c|c|c|c|c|}
\hline \multirow{2}{*}{ Position } & \multicolumn{2}{|l|}{1} & \multicolumn{2}{|l|}{2} & \multicolumn{2}{|l|}{3} & \multicolumn{2}{|l|}{4} \\
\hline & $\delta_{\mathrm{H}}, \mathrm{m}(J \text { in } \mathrm{Hz})^{a}$ & $\delta_{C}^{b}$, type & $\delta_{\mathrm{H}}, \mathrm{m}(J \text { in } \mathrm{Hz})^{a}$ & $\delta_{C}^{b}$, type & $\delta_{\mathrm{H}}, \mathrm{m}(J \text { in } \mathrm{Hz})^{c}$ & $\delta_{C}{ }^{d}$, type & $\delta_{\mathrm{H}}, \mathrm{m}(J \text { in } \mathrm{Hz})^{c}$ & $\delta_{C}{ }^{d}$, type \\
\hline 1 & & $160.7, \mathrm{C}$ & & $160.6, \mathrm{C}$ & & $160.6, \mathrm{C}$ & & $159.8, \mathrm{C}$ \\
\hline 2 & $\begin{array}{c}5.44, \mathrm{dd} \\
(10.0,1.6)\end{array}$ & $77.8, \mathrm{CH}$ & $\begin{array}{c}5.43, \mathrm{dd} \\
(10.0,1.6)\end{array}$ & $77.8, \mathrm{CH}$ & $\begin{array}{c}4.91, \mathrm{dd} \\
(10.0,1.6)\end{array}$ & $78.4, \mathrm{CH}$ & $\begin{array}{l}4.98, \mathrm{~d} \\
(10.4)\end{array}$ & $77.8, \mathrm{CH}$ \\
\hline 3 & $\begin{array}{c}4.90, \mathrm{~d} \\
(10.0)\end{array}$ & $122.2, \mathrm{CH}$ & $\begin{array}{c}4.91, \mathrm{~d} \\
(10.0)\end{array}$ & $122.7, \mathrm{CH}$ & $\begin{array}{c}4.55, \mathrm{~d} \\
(10.0)\end{array}$ & $123.9, \mathrm{CH}$ & $\begin{array}{l}4.45, \mathrm{~d} \\
(10.4)\end{array}$ & $123.5, \mathrm{CH}$ \\
\hline 4 & & 141.6, C & & $140.8, \mathrm{C}$ & & $140.2, \mathrm{C}$ & & 139.4, C \\
\hline $5 \alpha$ & $2.20, \mathrm{~m}$ & $47.9, \mathrm{CH}_{2}$ & $\begin{array}{c}2.18, \mathrm{dd} \\
(12.4,10.8)\end{array}$ & $42.6, \mathrm{CH}_{2}$ & $\begin{array}{c}2.42, \mathrm{dd} \\
(12.0,3.2)\end{array}$ & 49.1, $\mathrm{CH}_{2}$ & $1.98, \mathrm{~m}$ & $49.3, \mathrm{CH}_{2}$ \\
\hline $5 \beta$ & $\begin{array}{c}2.76, \mathrm{dd} \\
(12.8,5.2)\end{array}$ & & $\begin{array}{c}2.87, \mathrm{dd} \\
(12.4,4.4)\end{array}$ & & $189, \mathrm{~m}$ & & $\begin{array}{c}2.25, \mathrm{dd} \\
(12.8,3.6)\end{array}$ & \\
\hline 6 & $\begin{array}{c}4.70, \text { ddd } \\
(10.4,10.4,5.2)\end{array}$ & $65.2, \mathrm{CH}$ & $\begin{array}{c}4.97, \text { ddd } \\
(10.8,9.2,4.4)\end{array}$ & $78.3, \mathrm{CH}$ & $\begin{array}{l}3.84, \mathrm{dd} \\
(9.2,9.2)\end{array}$ & 69.6, $\mathrm{CH}$ & $\begin{array}{c}4.21, \text { ddd } \\
(11.2,9.2,3.6)\end{array}$ & $64.8, \mathrm{CH}$ \\
\hline $\begin{array}{l}7 \\
8\end{array}$ & $5.20, \mathrm{~d}(10.4)$ & $\begin{array}{c}128.1, \mathrm{CH} \\
139.8, \mathrm{C}\end{array}$ & $5.05, \mathrm{~d}(9.2)$ & $\begin{array}{c}123.1, \mathrm{CH} \\
144.2, \mathrm{C}\end{array}$ & $5.09, \mathrm{~d}(9.2)$ & $\begin{array}{c}131.6, \mathrm{CH} \\
138.4, \mathrm{C}\end{array}$ & $4.84, \mathrm{~d}(9.2)$ & $\begin{array}{c}131.2, \mathrm{CH} \\
139.4, \mathrm{C}\end{array}$ \\
\hline $9 \alpha$ & $2.03, \mathrm{~m}$ & $36.8, \mathrm{CH}_{2}$ & $2.07, \mathrm{~m}$ & $36.9, \mathrm{CH}_{2}$ & $\begin{array}{c}2.21, \mathrm{ddd} \\
(13.6,13.6,2.4)\end{array}$ & $28.2, \mathrm{CH}_{2}$ & $1.58, \mathrm{~m}$ & $28.5, \mathrm{CH}_{2}$ \\
\hline $9 \beta$ & $2.38, \mathrm{~m}$ & & $2.42, \mathrm{~m}$ & & $1.63, \mathrm{~m}$ & & $\begin{array}{c}2.30, \mathrm{dd} \\
(13.2,4.8)\end{array}$ & \\
\hline $\begin{array}{l}10 \alpha \\
10 \beta\end{array}$ & $\begin{array}{l}1.29, \mathrm{~m} \\
2.51, \mathrm{~m}\end{array}$ & $23.5, \mathrm{CH}_{2}$ & $\begin{array}{l}1.35, \mathrm{~m} \\
2.17, \mathrm{~m}\end{array}$ & 23.6, $\mathrm{CH}_{2}$ & $\begin{array}{l}1.16, \mathrm{~m} \\
1.84, \mathrm{~m}\end{array}$ & 23.9, $\mathrm{CH}_{2}$ & 1.60, m & $22.7, \mathrm{CH}_{2}$ \\
\hline 11 & $\begin{array}{c}2.42, \mathrm{dd} \\
(10.8,2.8)\end{array}$ & $61.4, \mathrm{CH}$ & $2.43, \mathrm{~m}$ & $61.4, \mathrm{CH}$ & $\begin{array}{c}2.24, \mathrm{dd} \\
(10.4,2.4)\end{array}$ & $58.9, \mathrm{CH}$ & $1.98, \mathrm{~m}$ & $62.6, \mathrm{CH}$ \\
\hline 12 & & $60.8, \mathrm{C}$ & & $60.8, \mathrm{C}$ & & $59.7, \mathrm{CH}$ & & $60.9, \mathrm{C}$ \\
\hline $13 \alpha$ & $2.03, \mathrm{~m}$ & $36.9, \mathrm{CH}_{2}$ & $2.02, \mathrm{~m}$ & 37.0, $\mathrm{CH}_{2}$ & $1.49, \mathrm{~m}$ & $35.5, \mathrm{CH}_{2}$ & $1.61, \mathrm{~m}$ & 37.1, $\mathrm{CH}_{2}$ \\
\hline $13 \beta$ & $1.06, \mathrm{~m}$ & & $1.07, \mathrm{~m}$ & & $0.98, \mathrm{~m}$ & & $0.65, \mathrm{~m}$ & \\
\hline $14 \alpha$ & $2.49, \mathrm{~m}$ & 23.7, $\mathrm{CH}_{2}$ & $2.52, \mathrm{~m}$ & 23.7, $\mathrm{CH}_{2}$ & $1.58, \mathrm{~m}$ & 22.2, $\mathrm{CH}_{2}$ & $2.08, \mathrm{~m}$ & 23.1, $\mathrm{CH}_{2}$ \\
\hline $14 \beta$ & $2.01, \mathrm{~m}$ & & $2.03, \mathrm{~m}$ & & $1.58, \mathrm{~m}$ & & $1.65, \mathrm{~m}$ & \\
\hline 15 & & $123.8, \mathrm{C}$ & & $123.8, \mathrm{C}$ & & $123.8, \mathrm{C}$ & & 123.7, C \\
\hline 16 & & $174.4, \mathrm{C}$ & & $174.4, \mathrm{C}$ & & $173.9, \mathrm{C}$ & & 174.3, C \\
\hline 17 & $1.86, \mathrm{~s}$ & $8.8, \mathrm{CH}_{3}$ & $1.86, \mathrm{~s}$ & $8.7, \mathrm{CH}_{3}$ & $1.64, \mathrm{~s}$ & $8.8, \mathrm{CH}_{3}$ & $1.63, \mathrm{~s}$ & $8.8, \mathrm{CH}_{3}$ \\
\hline 18 & $1.70, \mathrm{~s}$ & $15.9, \mathrm{CH}_{3}$ & $1.72, \mathrm{~s}$ & $15.9, \mathrm{CH}_{3}$ & $1.31, \mathrm{~s}$ & $18.1, \mathrm{CH}_{3}$ & $1.28, \mathrm{~s}$ & $16.9, \mathrm{CH}_{3}$ \\
\hline 19 & $1.86, \mathrm{~s}$ & $14.9, \mathrm{CH}_{3}$ & $1.89, \mathrm{~s}$ & $15.3, \mathrm{CH}_{3}$ & $1.45, \mathrm{~s}$ & $22.2, \mathrm{CH}_{3}$ & $1.32, \mathrm{~s}$ & $21.8, \mathrm{CH}_{3}$ \\
\hline 20 & $1.33, \mathrm{~s}$ & $15.8, \mathrm{CH}_{3}$ & $1.33, \mathrm{~s}$ & $15.8, \mathrm{CH}_{3}$ & $1.00, \mathrm{~s}$ & $17.1, \mathrm{CH}_{3}$ & $0.99, \mathrm{~s}$ & $16.4, \mathrm{CH}_{3}$ \\
\hline $6-\mathrm{OOH}$ & & & 7.99, br s & & & & & \\
\hline
\end{tabular}


Cherbonolide C (3) should have the same molecular formula as 1, according to HRESIMS data. Also, the ${ }^{1} \mathrm{H}-{ }^{1} \mathrm{H}$ COSY and HMBC correlations (Figure 2) of $\mathbf{3}$ are similar to those of $\mathbf{1}$, suggesting that these compounds possess almost the same molecular skeleton. Analysis of NOE correlations (Figure 5) showed that the relative configurations at $\mathrm{C}-2, \mathrm{C}-11$ and $\mathrm{C}-12$ in $\mathbf{1}$ and $\mathbf{3}$ are the same. Assuming the $\beta$-orientation of $\mathrm{H}-2$, as $\mathrm{H}_{3}-18$ showed $\mathrm{NOE}$ interaction with $\mathrm{H}-2$ but not with $\mathrm{H}-3$, the $E$ geometry was assigned to the trisubstituted C-3/C-4 double bond. One of the methylene protons at $C-5\left(\delta_{\mathrm{H}} 2.42, \mathrm{dd}\right.$, $J=12.0,3.2 \mathrm{~Hz}$ ) displayed NOE interaction with $\mathrm{H}-3$, but not with $\mathrm{H}_{3}-18$, and was hence determined as $\mathrm{H}-5 \alpha$. Further, $\mathrm{H}-6\left(\delta_{\mathrm{H}} 3.84, \mathrm{dd}, J=9.2,9.2 \mathrm{~Hz}\right)$ showed NOE correlations with $\mathrm{H}-5 \alpha$ and $\mathrm{H}-9 \alpha$, but not with $\mathrm{H}-9 \beta$ and $\mathrm{H}_{3}-19$. These observations, together with NOE correlations of $\mathrm{H}-9 \beta / \mathrm{H}_{3}-19$, $\mathrm{H}_{3}-19 / \mathrm{H}-7$ and $\mathrm{H}-7 / \mathrm{H}_{3}-18$, enabled deduction of the $\alpha$-orientation of $\mathrm{H}-6$ and led to the assignment of a $6 S^{*}$ configuration and a $Z$ geometry of the trisubstituted C-7/C-8 double bond in 3 . The olefinic methyl group attaching at $C-8$ showed carbon signal at $\delta_{C} 22.2 \mathrm{ppm}$ further confirmed the $Z$ geometry of C-7/C-8 double bond [30]. The absolute configuration of 3 at C- 6 was also verified by using the modified Mosher's method. Determination of the $\Delta \delta$ values $\left(\delta_{S}-\delta_{R}\right.$, shown in Figure 4$)$ for protons neighboring C-6 further confirmed the $S$ configuration at C-6 in 3 (Figure 4). The absolute configuration of 3 was thus assigned as $2 S, 6 S, 11 R$ and $12 R$. Thus, cherbonolide $C(3)$ is the $7 Z$ isomer of cherbonolide A (1).

Cherbonolide D (4) was found to be an isomer of 3 according to HRESIMS. Both compounds have almost the same ${ }^{1} \mathrm{H}-{ }^{1} \mathrm{H}$ COSY and $\mathrm{HMBC}$ correlations, indicating they have the same molecular skeleton. NMR data of 3 and 4 are nearly the same (Table 1), except for those of $\mathrm{CH}-6$, suggesting that 4 could be the $C-6$ epimer of 3 . The $(2 S, 6 R, 11 R, 12 R)$-configuration and the $E$ and $Z$ geometries of C-3/C-4 and C-7/C-8 double bonds of 4, respectively, were also established by analysis of NOE correlations to be as those of 3 (Figure 5).

Cherbonolide $\mathrm{E}$ (5) was determined to have a molecular formula $\mathrm{C}_{20} \mathrm{H}_{28} \mathrm{O}_{5}$ from its HRESIMS data $\left(m / z\right.$ calcd 371.1830; found 371.1829, $\left.[\mathrm{M}+\mathrm{Na}]^{+}\right)$, with one more oxygen than in 4 . Compounds 4 and 5 displayed almost identical ${ }^{1} \mathrm{H}$ and ${ }^{13} \mathrm{C}$ NMR data (Table 2), except for those of $\mathrm{CH}-6$. It was found that the hydroxy substituent of 4 at $\mathrm{C}-6$ was replaced by a hydroperoxy group in 5 , with the characteristic signal of a broad singlet at $\delta_{\mathrm{H}} 7.25[26,33,34]$. The obvious downfield shifts of C- $6\left(\delta_{\mathrm{C}} 64.8\right.$ in 4, 78.9 in 5) and $\mathrm{H}-6\left(\delta_{\mathrm{H}} 4.21\right.$ in $4,4.58$ in 5$)$ also confirmed the substitution of a hydroperoxy group at C-6 of 5 . Furthermore, reduction of 5 with triphenylphosphine could afford 4 . Therefore, the structure of 5 , with the $(2 S, 6 R, 11 R, 12 R)$-configuration, was determined.

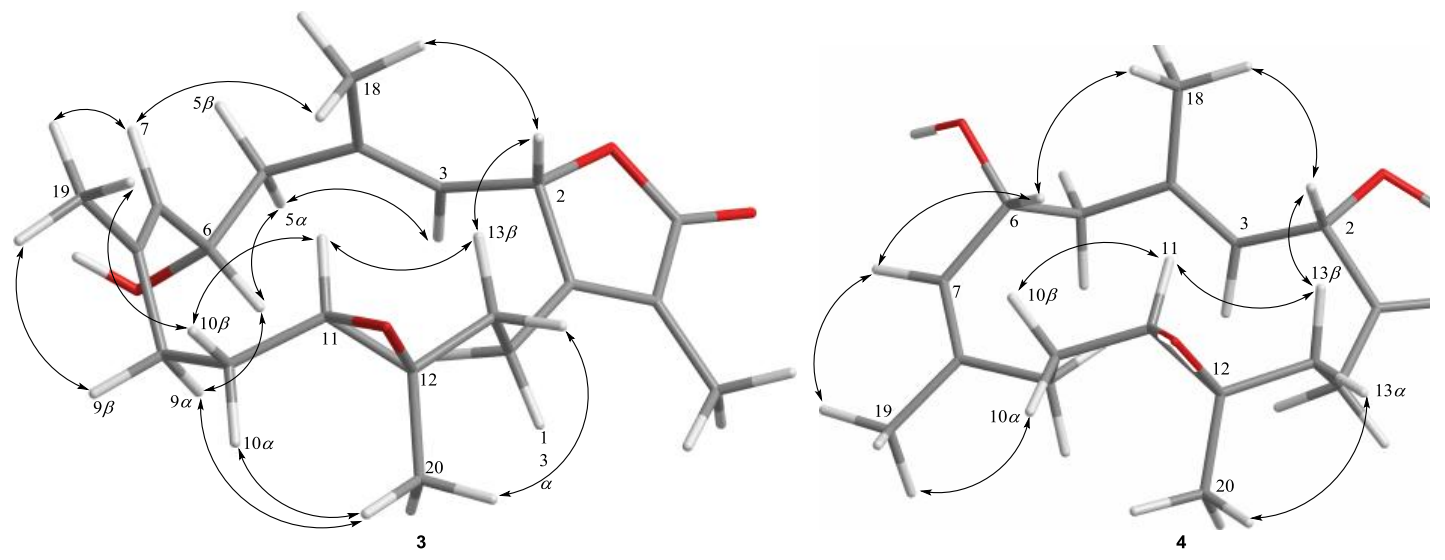

Figure 5. Key NOESY correlations for 3 and 4. 
Table 2. ${ }^{1} \mathrm{H}$ and ${ }^{13} \mathrm{C}$ NMR chemical shifts for compounds 5 and 6 .

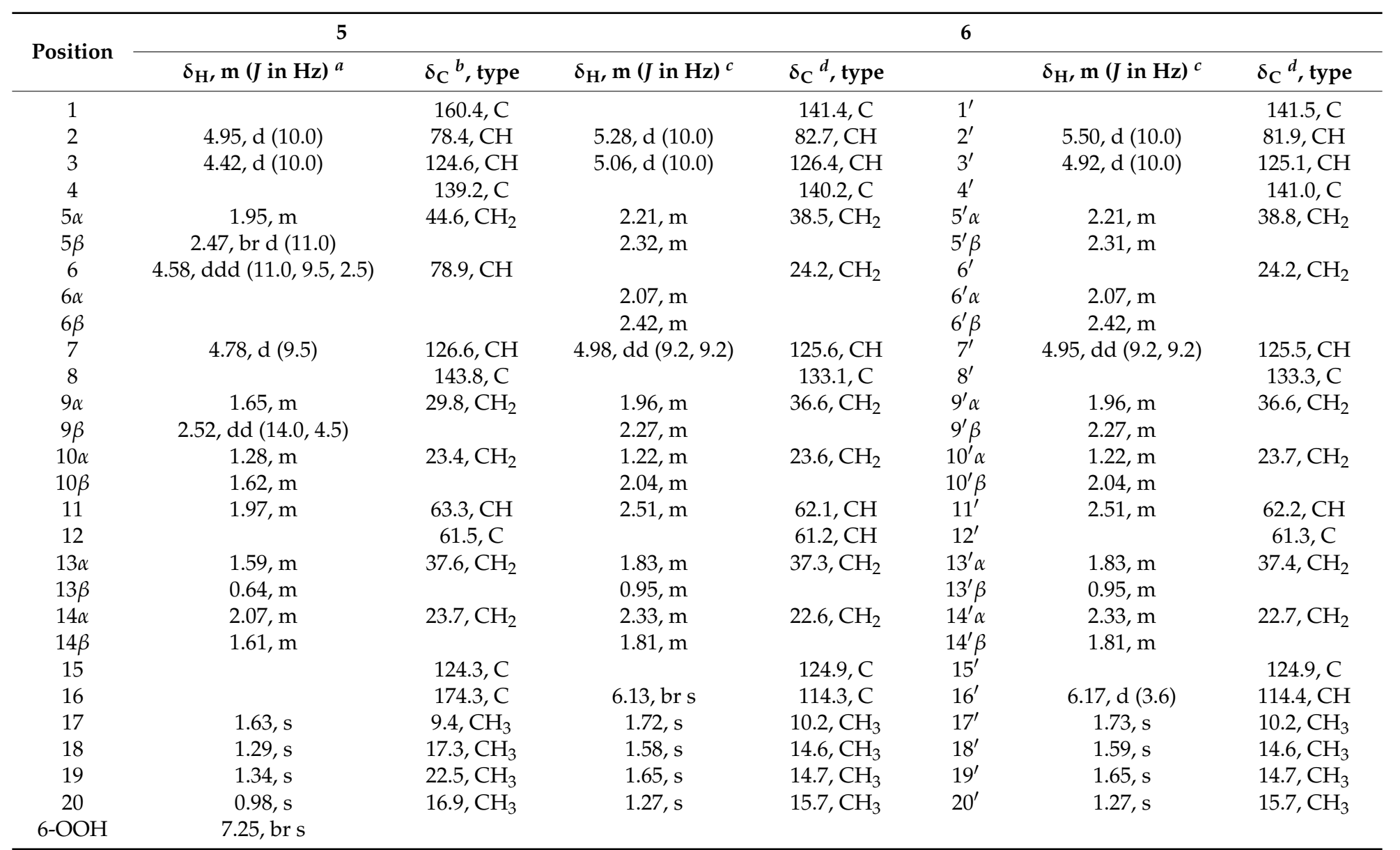

${ }^{a}$ Spectrum recorded at $500 \mathrm{MHz}$ in $\mathrm{C}_{6} \mathrm{D}_{6} \cdot{ }^{b}$ Spectrum recorded at $125 \mathrm{MHz}$ in $\mathrm{C}_{6} \mathrm{D}_{6} \cdot{ }^{c}$ Spectrum recorded at $400 \mathrm{MHz}$ in $\mathrm{CDCl}_{3} .{ }^{d}{\text { Spectrum recorded at } 100 \mathrm{MHz} \text { in } \mathrm{CDCl}}_{3}$. 
Bischerbolide peroxide (6) was afforded as a white powder with the molecular formula $\mathrm{C}_{40} \mathrm{H}_{58} \mathrm{O}_{6}$ from HRESIMS $\left(\mathrm{m} / \mathrm{z}\right.$ calcd 657.4124; found 657.4125, $\left.[\mathrm{M}+\mathrm{Na}]^{+}\right)$, appropriate for twelve degrees of unsaturation. The ${ }^{13} \mathrm{C}$ NMR spectroscopic data of 6 revealed the presence of 40 carbons (Table 2). The DEPT spectra of 6 showed the presence of eight methyls, twelve $s p^{3}$ methylenes, six sp $p^{3}$ oxygenated methines, four $s p^{2}$ methines, two $s p^{3}$ and eight $s p^{2}$ nonprotoned carbons (including two ester carbonyls). NMR signals resonating at $\delta_{\mathrm{C}} 114.3(\mathrm{CH}), 141.4(\mathrm{C}), 124.9(\mathrm{C}), 82.7(\mathrm{CH})$ and $10.2\left(\mathrm{CH}_{3}\right)$, and $\delta_{\mathrm{H}} 5.28$ $(1 \mathrm{H}, \mathrm{d}, J=10.0 \mathrm{~Hz})$ and $\delta_{\mathrm{H}} 1.72(3 \mathrm{H}, \mathrm{s})$, and another group of signals observed at $\delta_{\mathrm{C}} 114.4(\mathrm{CH}), 141.5$ $(\mathrm{C}), 124.9(\mathrm{C}), 81.9(\mathrm{CH})$ and $10.2\left(\mathrm{CH}_{3}\right)$, and $\delta_{\mathrm{H}} 5.50(1 \mathrm{H}, \mathrm{d}, J=10.0 \mathrm{~Hz})$ and $\delta_{\mathrm{H}} 1.73(3 \mathrm{H}, \mathrm{s})$, revealed the presence of two slightly different 2,5-dihydrofuran rings with a peroxyl group by comparison of the similar NMR data of five-membered rings in the literature [35]. Also, two groups of signals resonating at $\delta_{\mathrm{C}} 61.2(\mathrm{C}), 62.1(\mathrm{CH})$ and $\delta_{\mathrm{H}} 2.51(1 \mathrm{H}, \mathrm{m})$, and $\delta_{\mathrm{C}} 61.3(\mathrm{C}), 62.2(\mathrm{CH})$ and $\delta_{\mathrm{H}} 2.51(1 \mathrm{H}, \mathrm{m})$ showed the presence of two trisubstituted epoxides. Four trisubstituted olefinic bonds were revealed from NMR signals appearing at $\delta_{\mathrm{C}} 126.4(\mathrm{CH}), \delta_{\mathrm{C}} 140.2(\mathrm{C})$ and $\delta_{\mathrm{H}} 5.06(1 \mathrm{H}, \mathrm{d}, J=10.0 \mathrm{~Hz})$; at $\delta_{\mathrm{C}} 125.6$ $(\mathrm{CH}), \delta_{\mathrm{C}} 133.1(\mathrm{C})$ and $\delta_{\mathrm{H}} 4.98(1 \mathrm{H}, \mathrm{dd}, J=9.2,9.2 \mathrm{~Hz}) ;$ at $\delta_{\mathrm{C}} 125.1(\mathrm{CH}), \delta_{\mathrm{C}} 141.0(\mathrm{C})$ and $\delta_{\mathrm{H}} 4.92(1 \mathrm{H}$, $\mathrm{dd}, J=10.0 \mathrm{~Hz})$; and at $\delta_{\mathrm{C}} 125.5(\mathrm{CH}), \delta_{\mathrm{C}} 133.3(\mathrm{C})$ and $\delta_{\mathrm{H}} 4.95(1 \mathrm{H}, \mathrm{dd}, J=9.2,9.2 \mathrm{~Hz})$, respectively.

As the ${ }^{13} \mathrm{C}$ NMR spectrum of 6 was constituted by twenty sets of signals with each set containing two peaks of very similar chemical shifts, 6 was thus identified as a compound formed from the connection of two quite similar diterpenoid subunits. The entire planar structure was established by examination of ${ }^{1} \mathrm{H}$ and ${ }^{13} \mathrm{C}$ NMR data and ${ }^{1} \mathrm{H}^{1}{ }^{1} \mathrm{H}$ COSY and HMBC correlations (Figure 6). Two methines resonating at $\delta_{C} 114.3$ and $\delta_{C} 114.4$ were considered to be the positions at which the two cembranoidal units were connected by insertion of a peroxyl group. Based on the above analyses, the molecular skeleton of $\mathbf{6}$ was elucidated as the biscembranoid formed by the connection of two molecules of isosarcophytoxide [36] via a peroxyl group at C-16 and C-16'. The fragmentation pattern of ESIMS (Figure 7) could further prove the dimeric nature of 6 and the peroxyl linkage at $\mathrm{C}-16 / \mathrm{C}-16^{\prime}$. One ion peak displayed at $\mathrm{m} / \mathrm{z} 339$ can be explained by the cleavage of $\mathrm{O}-\mathrm{O}$ bond and the following elimination of $\mathrm{H}-16$ from a monocembranoidal unit in $\mathbf{6}$ to form a sodiated cembranoid lactone molecular ion A (pathway a). The other ion peaks can be interpreted by the cleavage of the single bond between C-16 and peroxyl oxygen to afford ion B $(\mathrm{m} / \mathrm{z} 301)$, and a peroxycembranoidal radical which could further abstract an hydrogen atom and form the sodium adduct $C(\mathrm{~m} / \mathrm{z} 357)$ (pathway b). Moreover, compound 6 was found to be the first example of a biscembranoid with a molecular skeleton formed by two cembranoid units connected by a peroxyl group.

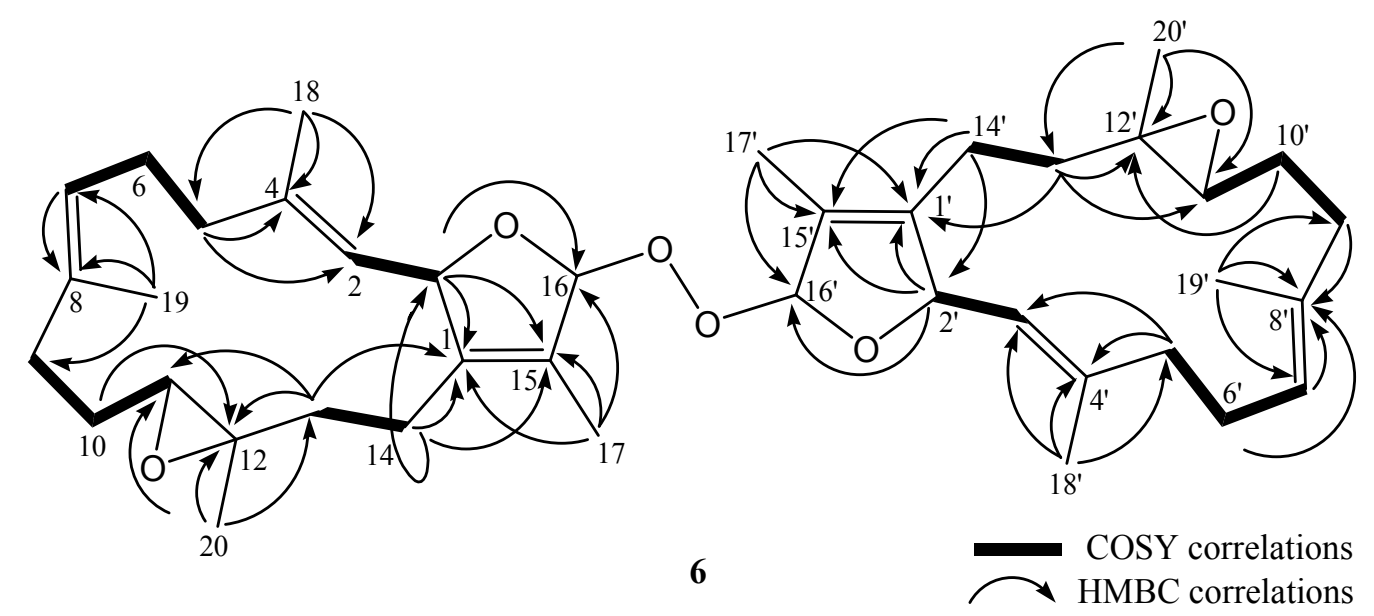

Figure 6. Selected ${ }^{1} \mathrm{H}-{ }^{1} \mathrm{H}$ COSY and HMBC correlations of 6. 


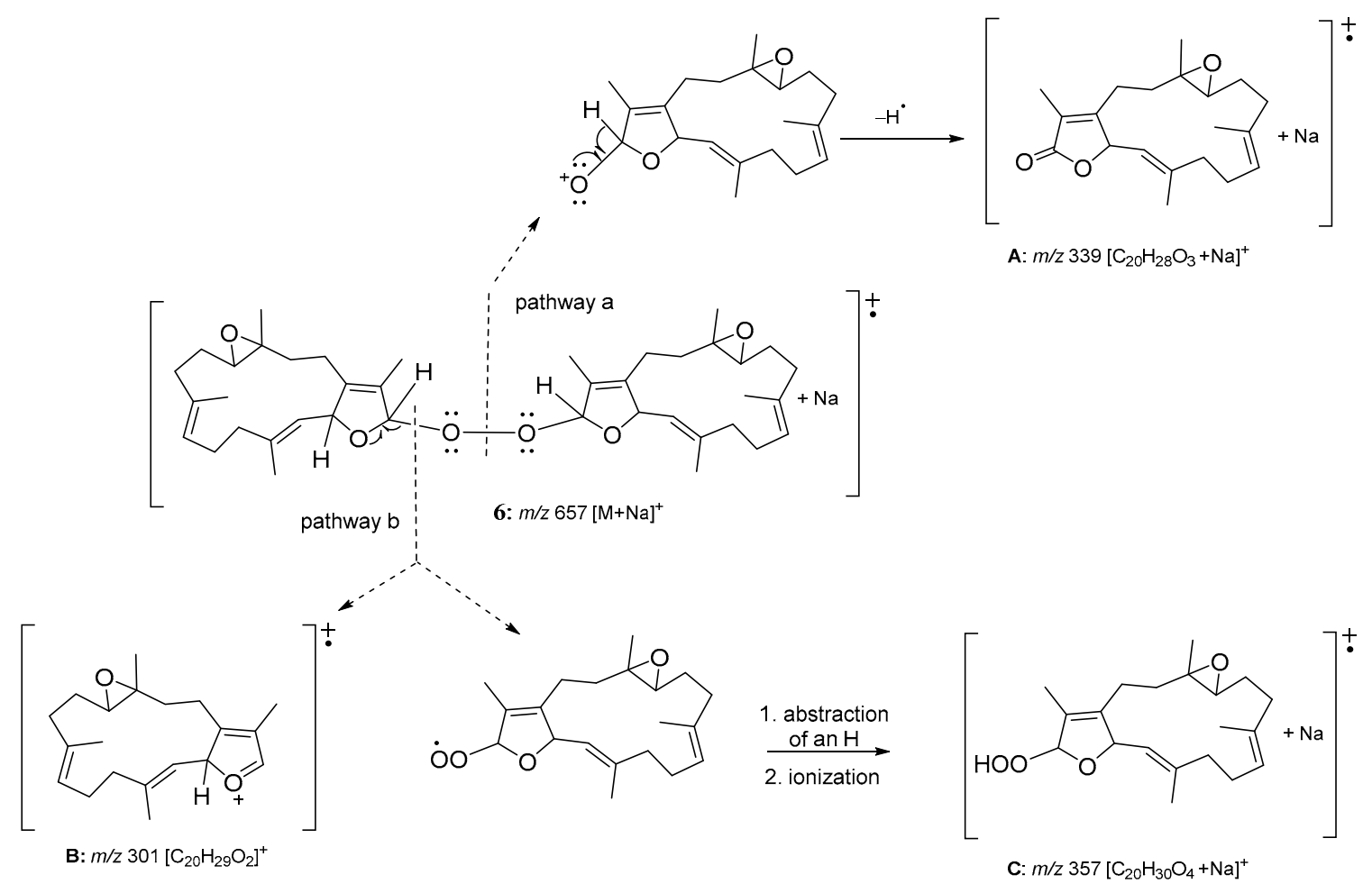

Figure 7. ESIMS fragmentation of 6.

The relative configuration of $\mathbf{6}$ was determined from a literature survey [36,37] and NOE correlations (Figure 8). The ${ }^{13} \mathrm{C}$ NMR spectrum of 6 displayed 40 signals of two sets signals with nearly identical chemical shifts, representing the very similar stereochemical environments of the two structural units. In addition, compound 6 was found to have nearly identical chemical shifts for $\mathrm{H}-11\left(11^{\prime}\right), \mathrm{H}_{3}-18\left(18^{\prime}\right), \mathrm{H}_{3}-20\left(20^{\prime}\right)$ and C-20 (20') to those of $(2 S, 11 R, 12 R)$-isosarcophytoxide (8), and were in turn found to exhibit distinguishable differences to the corresponding chemical shifts of $(2 R, 11 R, 12 R)$-isosarcophytoxide (9) (Table 3 and Figure 9). Thus, 6 possessed the cembranoidal structural unit derived from 8, as also proven by observed NOE correlations (Figure 8). Different proton values were observed for $\mathrm{H}-2\left(\delta_{\mathrm{H}} 5.28\right)$ and $\mathrm{H}-2^{\prime}\left(\delta_{\mathrm{H}} 5.50\right)$, indicating that $\mathrm{H}-2^{\prime}$ was on the same planar face as the peroxide group and was deshielded, and $\mathrm{H}-2$ was on the same planar face as $\mathrm{H}-16$ and was shielded. As compounds 1-7 were isolated from the same organism in this study, they are likely to possess the same absolute $S, R, R$-configurations at the chiral centers $C-2, C-11$ and C-12, respectively, as those of $\mathbf{1}$ and $\mathbf{3}$. A previous report also showed that different absolute configurations at C-2 of the related diasteromeric dihydrofuran ring-containing cembranoids could significantly influence the sign of the specific optical rotation $[36,38]$. For cembranoids with $2 S$ configuration a significant positive and for those with $2 R$ configuration a negative optical rotation were found. The $[\alpha]_{\mathrm{D}}^{25}$ of 6 was +41 ; thus, the absolute configuration of 6 was deduced to be $2 S, 11 R, 12 R, 16 R, 2^{\prime} S, 11^{\prime} R, 12^{\prime} R, 16^{\prime} S$. 


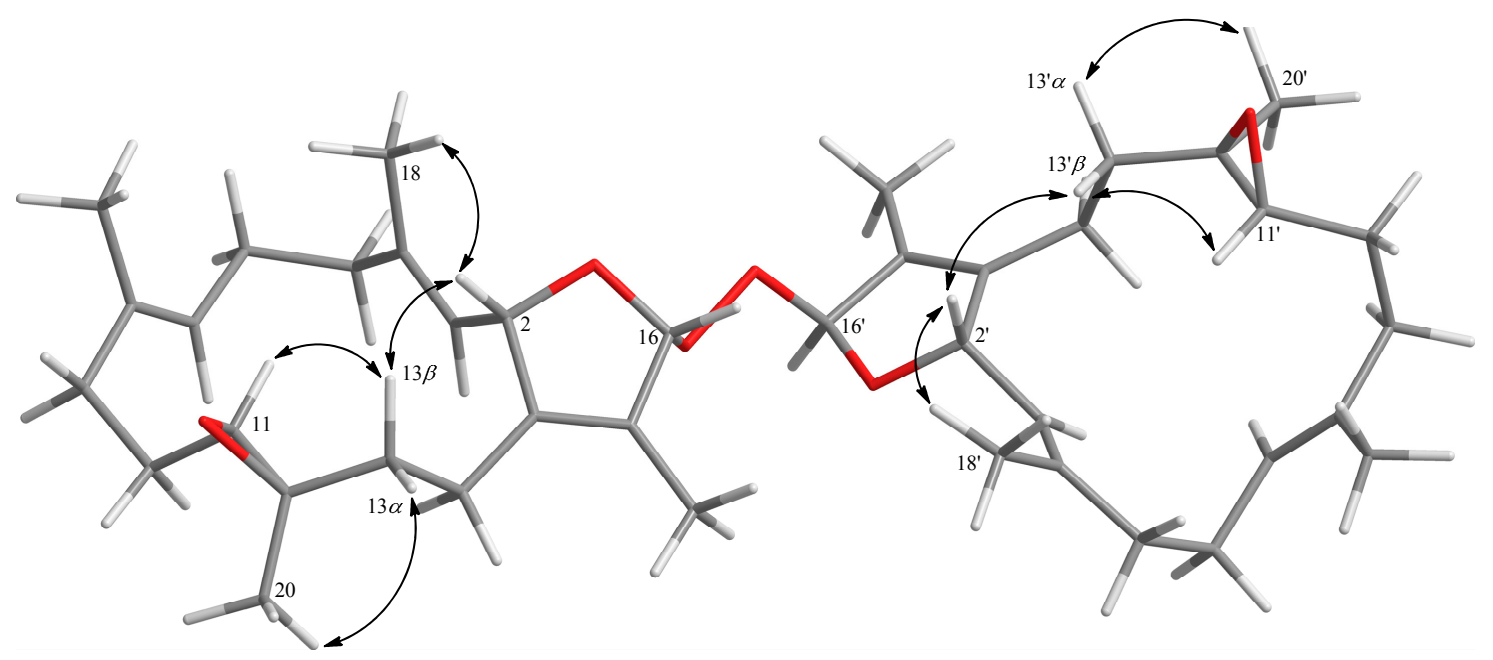

Figure 8. Selected NOESY correlations for 6.

Table 3. Selected ${ }^{1} \mathrm{H}$ and ${ }^{13} \mathrm{C}$ NMR data comparison with 6, $(2 S, 11 R, 12 R)$-isosarcophytoxide (8) and $(2 R, 11 R, 12 R)$-isosarcophytoxide (9).

\begin{tabular}{|c|c|c|c|}
\hline Position & 6 & $8^{a}$ & $9^{a}$ \\
\hline $\mathrm{H}-11$ & $\delta_{\mathrm{H}} 2.51\left(\mathrm{H}-11, \mathrm{H}-11^{\prime}\right)$ & $\delta_{\mathrm{H}} 2.50$ & $\delta_{\mathrm{H}} 2.75$ \\
\hline C-11 & $\begin{array}{l}\delta_{C} 62.1(\mathrm{C}-11) \\
\delta_{C} 62.2\left(\mathrm{C}-11^{\prime}\right)\end{array}$ & $\delta_{C} 62.3$ & $\delta_{C} 61.2$ \\
\hline $\mathrm{C}-12$ & $\begin{array}{l}\delta_{\mathrm{C}} 61.2(\mathrm{C}-12) \\
\delta_{\mathrm{C}} 61.3\left(\mathrm{C}-12^{\prime}\right)\end{array}$ & $\delta_{C} 61.4$ & $\delta_{C} 60.7$ \\
\hline C-13 & $\begin{array}{l}\delta_{C} 37.3(\mathrm{C}-13) \\
\delta_{C} 37.4\left(\mathrm{C}-13^{\prime}\right)\end{array}$ & $\delta_{C} 37.4$ & $\delta_{C} 35.4$ \\
\hline C-14 & $\begin{array}{l}\delta_{C} 22.6(\mathrm{C}-14) \\
\delta_{C} 22.7\left(\mathrm{C}-14^{\prime}\right)\end{array}$ & $\delta_{C} 22.5$ & $\delta_{C} 20.4$ \\
\hline $\mathrm{H}_{3}-18$ & $\begin{array}{c}\delta_{\mathrm{H}} 1.58\left(\mathrm{H}_{3}-18\right) \\
\delta_{\mathrm{H}} 1.59\left(\mathrm{H}_{3}-18^{\prime}\right)\end{array}$ & $\delta_{\mathrm{H}} 1.58$ & $\delta_{\mathrm{H}} 1.70$ \\
\hline $\mathrm{H}_{3}-20$ & $\delta_{\mathrm{H}} 1.27\left(\mathrm{H}_{3}-20, \mathrm{H}_{3}-20^{\prime}\right)$ & $\delta_{\mathrm{H}} 1.28$ & $\delta_{\mathrm{H}} 1.18$ \\
\hline $\mathrm{C}-20$ & $\delta_{C} 15.7\left(C-20, C-20^{\prime}\right)$ & $\delta_{C} 15.7$ & $\delta_{C} 17.7$ \\
\hline
\end{tabular}

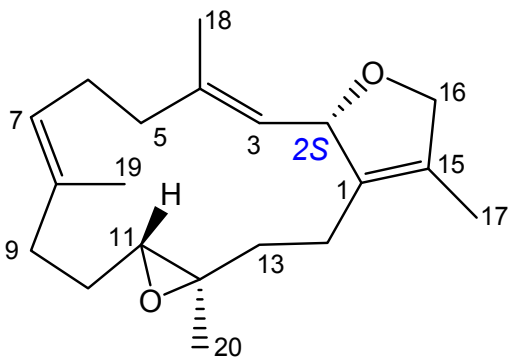

8

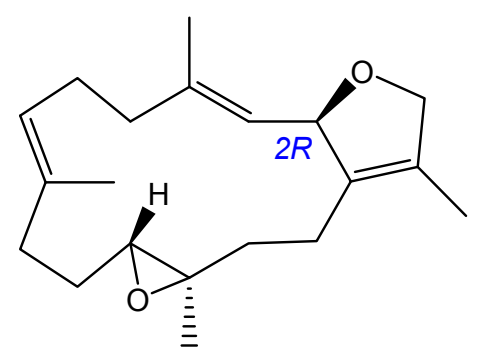

9

Figure 9. Structures of $(2 S, 11 R, 12 R)$-isosarcophytoxide (8) and $(2 R, 11 R, 12 R)$-isosarcophytoxide (9) [36].

The plausible biosynthesis of 6 might arise from the proton abstraction at C-16 of 8 by hydrogen peroxide radical $\mathrm{HOO} \bullet$ to form a radical intermediate 10 , which could react with $\mathrm{O}_{2}$ from one plane side of radical center C-16 to afford cembranoidal peroxide radical 11. Further reaction of 11 with 10 from another side could lead to the formation of $\mathbf{6}$ (Scheme 1). However, the possibility that $\mathbf{6}$ might be generated by autooxidation of $\mathbf{8}$ could not be neglected. 


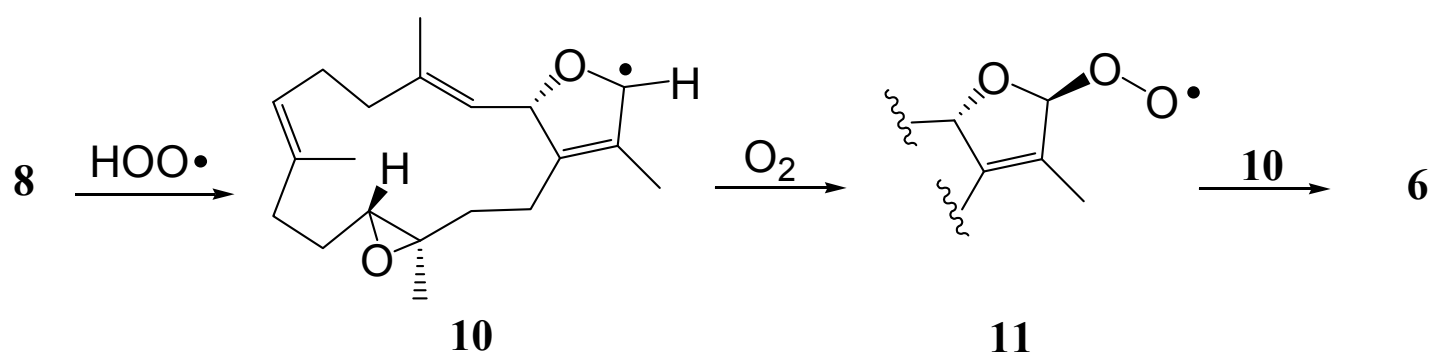

Scheme 1. Proposed biosynthetic pathway for 6 .

It is known that the proteolytic enzymes and toxic reactive oxygen species produced by stimulated neutrophils might play a critical role in the pathogenesis of many inflammatory diseases $[39,40]$. By measuring the capability to inhibit $N$-formyl-methionyl-leucyl-phenylalanine/cytochalasin B (fMLF/CB)-induced superoxide anion generation and elastase release in human neutrophils, the in vitro anti-inflammatory effects for metabolites 1-7 were evaluated [41,42]. According to the results (shown in Table 4), compound 6 had a significant inhibitory effect $(64.6 \pm 0.8 \%)$, with an $\mathrm{IC}_{50}$ value of $26.2 \pm 1.0 \mu \mathrm{M}$, on the generation of superoxide anions, and compounds $\mathbf{1}$ and $\mathbf{3}$ had moderate inhibitory effects ( $32.1 \pm 4.3 \%$ and $44.5 \pm 4.6 \%$, respectively) at $30 \mu \mathrm{M}$. Compounds 1,3 and 6 revealed moderate inhibitory effects ( $37.6 \pm 5.0 \%, 35.6 \pm 6.2 \%$ and $42.4 \pm 5.1 \%$, respectively) on elastase release at the same concentration. These results, obtained after stimualting the neutrophils with $\mathrm{fMLF} / \mathrm{CB}$, may suggest that 1, 3 and $\mathbf{6}$ have potential merits against inflammatory disorders.

Table 4. Inhibitory effects of compounds 1-7 on superoxide anion generation and elastase release in fMLF/CB-induced human neutrophils.

\begin{tabular}{cccc}
\hline \multirow{2}{*}{ Compounds } & \multicolumn{2}{c}{ Superoxide Anion } & Elastase Release \\
\cline { 2 - 4 } & $\mathbf{I C}_{\mathbf{5 0}}(\boldsymbol{\mu} \mathbf{M})^{\mathbf{a}}$ & $\operatorname{Inh}^{\mathbf{b}} \mathbf{\%}$ & Inh $^{\mathbf{b}} \mathbf{\%}$ \\
\hline $\mathbf{1}$ & $>30$ & $32.1 \pm 4.3^{* *}$ & $37.6 \pm 5.0^{* *}$ \\
$\mathbf{2}$ & $>30$ & $4.0 \pm 6.6^{* *}$ & $23.5 \pm 6.6^{*}$ \\
$\mathbf{3}$ & $>30$ & $44.5 \pm 4.6^{* *}$ & $35.6 \pm 6.2^{* *}$ \\
$\mathbf{4}$ & $>30$ & $6.4 \pm 4.2$ & $27.6 \pm 6.4^{* *}$ \\
$\mathbf{5}$ & $>30$ & $2.6 \pm 6.2$ & $30.5 \pm 4.6^{* *}$ \\
$\mathbf{6}$ & $26.2 \pm 1.0$ & $64.6 \pm 0.8^{* * *}$ & $42.4 \pm 5.1^{* *}$ \\
$\mathbf{7}$ & $>30$ & $3.5 \pm 5.3$ & $20.7 \pm 4.1^{* *}$ \\
Idelalisib & $0.07 \pm 0.01$ & $102.8 \pm 2.2^{* * *}$ & $99.6 \pm 4.2$ \\
\hline
\end{tabular}

a Concentration necessary for $50 \%$ inhibition $\left(\mathrm{IC}_{50}\right) .{ }^{\mathrm{b}}$ Percentage of inhibition (Inh \%) at $30 \mu \mathrm{M}$. Data are presented as mean \pm S.E.M. $(n=3-4){ }^{*} p<0.05,{ }^{* *} p<0.01,{ }^{* * *} p<0.001$ compared with the control value.

In summary, examination of the chemical constituents of the soft coral Sarcophyton cherbonnieri led to the discovery of six new compounds 1-6, along with one known compound 7. Although a number of natural compounds possessing a peroxyl group, such as artemisinin [43], neovibsanin C [44], cardamom peroxide [45], plakortin [46] and chondrillin [47], have been discovered, compound 6 was discovered to be the first compound with a molecular skeleton consisting of two cembranoidal units connected by a peroxide group. Similar to the results of previous studies indicating that natural peroxides could possess promising biological activity [48], compound 6 was found to possess anti-inflammatory activity by exhibiting stronger ability on inhibition on the generation of superoxide anions and release of elastase in $\mathrm{fMLF} / \mathrm{CB}$-induced human neutrophils. 


\section{Materials and Methods}

\subsection{General Procedures}

The values of optical rotation of the metabolites were determined with a JASCO P-1020 polarimeter (JASCO Corporation, Tokyo, Japan). Infrared absorptions were recorded using a JASCO FT/IR-4100 infrared spectrophotometer (JASCO Corporation, Tokyo, Japan). ${ }^{1} \mathrm{H}$ and ${ }^{13} \mathrm{C}$ NMR spectra were obtained on a Varian 400MR FT-NMR (or Varian Unity INOVA500 FT-NMR) instrument (Varian Inc., Palo Alto, CA, USA) at $400 \mathrm{MHz}$ (or $500 \mathrm{MHz}$ ) and $100 \mathrm{MHz}$ (or $125 \mathrm{MHz}$ ), respectively, in $\mathrm{CDCl}_{3}$ or $\mathrm{C}_{6} \mathrm{D}_{6}$. The data of LRESIMS and HRESIMS were measured using a Bruker APEX II (Bruker, Bremen, Germany) mass spectrometer. Silica gel (230-400 mesh) was used as adsorbent for column chromatography. TLC analyses were performed using precoated silica gel plates (Kieselgel 60 F-254, $0.2 \mathrm{~mm}$ ) (Merck, Darmstadt, Germany). Further purification of impure fractions or compounds were performed by high-performance liquid chromatography on a Hitachi L-7100 HPLC instrument (Hitachi Ltd., Tokyo, Japan) with a Merck Hibar Si-60 column (250 mm × $21 \mathrm{~mm}, 7 \mu \mathrm{m}$; Merck, Darmstadt, Germany) and on a Hitachi L-2455 HPLC apparatus (Hitachi, Tokyo, Japan) with a Supelco C18 column ( $250 \mathrm{~mm} \times 21.2 \mathrm{~mm}, 5 \mu \mathrm{m}$; Supelco, Bellefonte, PA, USA).

\subsection{Animal Material}

The soft coral S. cherbonnieri was collected by hand using scuba diving from Jihui Fish Port, Taiwan, in March 2013, at a depth of 10-15 m. Organisms of the marine animal were stored in a freezer until extraction.

\subsection{Extraction and Isolation}

The frozen marine organisms, S. cherbonnieri $(1.2 \mathrm{~kg}$, wet wt), were freeze-dried (yield: $207 \mathrm{~g}$ ), minced to small pieces and then extracted thoroughly with EtOAc $(1 \mathrm{~L} \times 5)$. The combined EtOAc extract (10.2 g) was concentrated under reduced pressure to yield a residue, which was chromatographed over a silica gel column by eluting with acetone in $n$-hexane (0-100\%, stepwise), and then with $\mathrm{MeOH}$ in acetone (0-100\%, stepwise) to yield 19 fractions. Fraction 9, eluting with $n$-hexane-acetone (6:1), was repeatedly purified by column chromatography over silica gel to yield a solid which was immersed in cold $\mathrm{MeOH}\left(0^{\circ} \mathrm{C}\right)$ to afford a white powder 6 (24.3 mg). Fraction 10, eluting with $n$-hexane-acetone (4:1), was further purified over silica gel using $n$-hexane-acetone (6:1) to afford seven subfractions (A1-A7) and afford 7 (320.4 mg). Subfraction A2 was further separated by reverse-phase HPLC using acetonitrile- $\mathrm{H}_{2} \mathrm{O}(1: 1.3)$ to afford $\mathbf{1}(11.0 \mathrm{mg})$. Subfraction A3 was purified by reverse-phase HPLC using acetonitrile- $\mathrm{H}_{2} \mathrm{O}(1: 1.1)$ to afford 2 (13.3 mg) and 5 (10.1 mg). Fraction 13, eluting with $n$-hexane-acetone (1:1), eluting with acetone by sephadex LH-20 to afford five subfractions (B1-B5). Subfraction B3 was purified by reverse-phase HPLC using acetonitrile- $\mathrm{H}_{2} \mathrm{O}(1: 1.4)$ to afford 3 (10.6 mg) and 4 (9.4 mg).

\subsubsection{Cherbonnolide A (1)}

Colorless oil; $[\alpha]_{\mathrm{D}}^{25}+43$ (c 1.00, $\mathrm{CHCl}_{3}$ ); IR (neat) $v_{\max } 3444,1746$, and $1003 \mathrm{~cm}^{-1} ;{ }^{13} \mathrm{C}$ and ${ }^{1} \mathrm{H}$ NMR data see Table 1; HRMS (ESI-TOF) $m / z$ : $[\mathrm{M}+\mathrm{Na}]^{+}$Calcd for $\mathrm{C}_{20} \mathrm{H}_{28} \mathrm{O}_{4} \mathrm{Na}$ 355.1880; Found 355.1879.

\subsubsection{Cherbonnolide B (2)}

Colorless oil; $[\alpha]_{\mathrm{D}}^{25}+59$ (c 1.00, $\mathrm{CHCl}_{3}$ ); IR (neat) $\nu_{\max } 3363,1741,1678$, and $1093 \mathrm{~cm}^{-1} ;{ }^{13} \mathrm{C}$ and ${ }^{1} \mathrm{H}$ NMR data see Table 1 ; HRMS (ESI-TOF) $m / z$ : $[\mathrm{M}+\mathrm{Na}]^{+}$Calcd for $\mathrm{C}_{20} \mathrm{H}_{28} \mathrm{O}_{5} \mathrm{Na} 371.1829$; Found 371.1830. 


\subsubsection{Cherbonnolide C (3)}

Colorless oil; $[\alpha]_{\mathrm{D}}^{25}+26\left(c\right.$ 1.00, $\left.\mathrm{CHCl}_{3}\right)$; IR (neat) $v_{\max } 3445,1749,1678$, and $1094 \mathrm{~cm}^{-1} ;{ }^{13} \mathrm{C}$ and ${ }^{1} \mathrm{H}$ NMR data see Table 1; HRMS (ESI-TOF) $m / z$ : $[\mathrm{M}+\mathrm{Na}]^{+}$Calcd for $\mathrm{C}_{20} \mathrm{H}_{28} \mathrm{O}_{4} \mathrm{Na} 355.1880$; Found 355.1882.

\subsubsection{Cherbonnolide D (4)}

White powder; $[\alpha]_{\mathrm{D}}^{25}+3\left(c 1.00, \mathrm{CHCl}_{3}\right)$; IR (neat) $v_{\max } 3445,1748$, and $1096 \mathrm{~cm}^{-1} ;{ }^{13} \mathrm{C}$ and ${ }^{1} \mathrm{H} \mathrm{NMR}$ data see Table 1; HRMS (ESI-TOF) $\mathrm{m} / z$ : $[\mathrm{M}+\mathrm{Na}]^{+}$Calcd for $\mathrm{C}_{20} \mathrm{H}_{28} \mathrm{O}_{4} \mathrm{Na}$ 355.1880; Found 355.1883.

\subsubsection{Cherbonnolide E (5)}

Colorless oil; $[\alpha]_{\mathrm{D}}^{25}+8\left(c\right.$ 1.00, $\left.\mathrm{CHCl}_{3}\right)$; IR (neat) $v_{\max } 3389,1748,1678$ and $1096 \mathrm{~cm}^{-1} ;{ }^{13} \mathrm{C}$ and ${ }^{1} \mathrm{H}$ NMR data see Table 2; HRMS (ESI-TOF) $m / z$ : $[\mathrm{M}+\mathrm{Na}]^{+} \mathrm{Calcd}$ for $\mathrm{C}_{20} \mathrm{H}_{28} \mathrm{O}_{5} \mathrm{Na}$ 371.1829; Found 371.1830.

\subsubsection{Bischerbolide Peroxide (6)}

White powder; $[\alpha]_{\mathrm{D}}^{25}+41\left(c\right.$ 1.00, $\left.\mathrm{CHCl}_{3}\right)$; IR (neat) $v_{\max } 3420,1733,1232,1166$ and $1040 \mathrm{~cm}^{-1}$; ${ }^{13} \mathrm{C}$ and ${ }^{1} \mathrm{H}$ NMR data see Table 2; HRMS (ESI-TOF) $m / z$ : $[\mathrm{M}+\mathrm{Na}]^{+} \mathrm{Calcd}$ for $\mathrm{C}_{40} \mathrm{H}_{58} \mathrm{O}_{6} \mathrm{Na}$ 657.4125; Found 657.4124.

\subsubsection{Reduction of Cherbonolides B and E (2 and 5)}

In diethyl ether $(5.0 \mathrm{~mL})$, compound $2(3.2 \mathrm{mg})$ was added followed by addition of excess amount of triphenylphosphine $(2.9 \mathrm{mg})$ and the mixture was stirred at room temperature for $4 \mathrm{~h}$. The solvent of the solution was evaporated under reduced pressure to afford a residue, which was purified by silica gel column chromatography using $n$-hexane-acetone (3:1) as an eluent to yield $\mathbf{1}(2.9 \mathrm{mg}, 95 \%)$. Similarly, 5 ( $2.1 \mathrm{mg})$ was converted to $4(1.7 \mathrm{mg})$ in $85 \%$ yield.

\subsubsection{Preparation of (S)- and (R)- MTPA Esters of $\mathbf{1}$ and $\mathbf{3}$}

Compound 1 (1.3 mg) was dissolved in pyridine $100 \mu \mathrm{L}$ and added (R)-(-)- $\alpha$-methoxy- $\alpha$-(trifluoromethyl) phenylacetyl chloride (MTPA chloride) $10 \mu \mathrm{L}$. The mixture was permitted to stand at room temperature overnight and the reaction was found to complete by monitoring with normal-phase TLC plate. The solution was dried completely under the vacuum of an oil pump and the residue was purified by a short silica gel column using acetone to $n$-hexane (1:3) to yield the (S)-MTPA ester 1a $(0.9 \mathrm{mg}, 62.9 \%)$. The same procedure was applied to obtain the $(R)$-MTPA ester $\mathbf{1 b}(1.0 \mathrm{mg}, 69.9 \%)$ from the reaction of $(S)-(+)-\alpha$-methoxy- $\alpha$-(trifluoromethyl) phenylacetyl chloride with 1 in pyridine. Selective ${ }^{1} \mathrm{H}$ NMR $\left(\mathrm{CDCl}_{3}, 400 \mathrm{MHz}\right)$ data of $1 \mathrm{a}: \delta_{\mathrm{H}} 4.925$ $(1 \mathrm{H}, \mathrm{d}, J=10.0 \mathrm{~Hz}, \mathrm{H}-3), 1.769\left(3 \mathrm{H}, \mathrm{s}, \mathrm{H}_{3}-18\right), 2.821(1 \mathrm{H}, \mathrm{dd}, J=12.8,4.8 \mathrm{~Hz}, \mathrm{H}-5 \mathrm{a}), 2.376(1 \mathrm{H}, \mathrm{m}, \mathrm{H}-5 \mathrm{~b})$, $5.107(1 \mathrm{H}, \mathrm{d}, J=9.6 \mathrm{~Hz}, \mathrm{H}-7), 1.880\left(3 \mathrm{H}, \mathrm{s}, \mathrm{H}_{3}-19\right), 2.460(1 \mathrm{H}, \mathrm{m}, \mathrm{H}-9 \mathrm{a}), 1.989(1 \mathrm{H}, \mathrm{m}, \mathrm{H}-9 \mathrm{~b})$; selective ${ }^{1} \mathrm{H} \mathrm{NMR}\left(\mathrm{CDCl}_{3}, 400 \mathrm{MHz}\right)$ data of $\mathbf{1 b}: \delta_{\mathrm{H}} 4.905(1 \mathrm{H}, \mathrm{d}, J=10.0 \mathrm{~Hz}, \mathrm{H}-3), 1.763\left(3 \mathrm{H}, \mathrm{s}, \mathrm{H}_{3}-18\right), 2.739$ $(1 \mathrm{H}, \mathrm{dd}, J=12.8,5.6 \mathrm{~Hz}, \mathrm{H}-5 \mathrm{a}), 2.267(1 \mathrm{H}, \mathrm{m}, \mathrm{H}-5 \mathrm{~b}), 5.217(1 \mathrm{H}, \mathrm{d}, J=9.6 \mathrm{~Hz}, \mathrm{H}-7), 1.905\left(3 \mathrm{H}, \mathrm{s}, \mathrm{H}_{3}-19\right)$, 2.476 (1H, m, H-9a), 1.998 (1H, m, H-9b).

Preparation of $(S)$ - and $(R)$ - MTPA esters of 3 used the same reaction and purification procedures as the reduction of $\mathbf{1}$, the solution of $\mathbf{3}(1.1 \mathrm{mg})$ was converted to the (S)-MTPA ester $\mathbf{3 a}(0.8 \mathrm{mg})$ in $74 \%$ yield and (R)-MTPA ester $3 \mathbf{b}(0.9 \mathrm{mg})$ in $80 \%$ yield, respectively. Selective ${ }^{1} \mathrm{HNMR}\left(\mathrm{C}_{6} \mathrm{D}_{6}, 400 \mathrm{MHz}\right)$ data of 3a: $\delta_{\mathrm{H}} 1.243\left(3 \mathrm{H}, \mathrm{s}, \mathrm{H}_{3}-18\right), 2.311(1 \mathrm{H}, \mathrm{dd}, J=11.2,2.4 \mathrm{~Hz}, \mathrm{H}-5 \mathrm{a}), 1.930(1 \mathrm{H}, \mathrm{dd}, J=11.2,11.2 \mathrm{~Hz}$, $\mathrm{H}-5 \mathrm{~b}), 5.065(1 \mathrm{H}, \mathrm{d}, J=9.2 \mathrm{~Hz}, \mathrm{H}-7), 1.416\left(3 \mathrm{H}, \mathrm{s}, \mathrm{H}_{3}-19\right)$; selective ${ }^{1} \mathrm{H}$ NMR $\left(\mathrm{C}_{6} \mathrm{D}_{6}, 400 \mathrm{MHz}\right)$ data of 3b: $\delta_{\mathrm{H}} 1.244\left(3 \mathrm{H}, \mathrm{s}, \mathrm{H}_{3}-18\right), 2.363(1 \mathrm{H}, \mathrm{dd}, J=12.0,3.2 \mathrm{~Hz}, \mathrm{H}-5 \mathrm{a}), 1.982(1 \mathrm{H}, \mathrm{dd}, J=12.0,11.6 \mathrm{~Hz}, \mathrm{H}-5 \mathrm{~b})$, $4.9515(1 \mathrm{H}, \mathrm{d}, J=10.0 \mathrm{~Hz}, \mathrm{H}-7), 1.360\left(3 \mathrm{H}, \mathrm{s}, \mathrm{H}_{3}-19\right)$. 


\subsection{In Vitro Anti-Inflammatory Testing}

\subsubsection{Human Neutrophils}

Blood was obtained from elbow vein of healthy adult volunteers (years 20-30). Neutrophils were enriched by dextran sedimentation, Ficoll-Hypaque centrifugation, and hypotonic lysis. Neutrophils were incubated in an ice-cold $\mathrm{Ca}^{2+}$-free HBSS buffer ( $\mathrm{pH}$ 7.4) [42].

\subsubsection{Superoxide Anion Generation}

Neutrophils $\left(6 \times 10^{5}\right.$ cells $\left.\mathrm{mL}^{-1}\right)$ incubated in HBSS with ferricytochrome $c\left(0.5 \mathrm{mg} \mathrm{mL}^{-1}\right)$ and $\mathrm{Ca}^{2+}(1 \mathrm{mM})$ at $37^{\circ} \mathrm{C}$ were treated with DMSO (as control) or compound for $5 \mathrm{~min}$. Neutrophils were primed by cytochalasin $\mathrm{B}\left(\mathrm{CB}, 1 \mu \mathrm{g} \mathrm{mL}{ }^{-1}\right)$ for $3 \mathrm{~min}$ before activating fMLF (100 $\left.\mathrm{nM}\right)$ for $10 \mathrm{~min}$ (fMLF/CB) [40,49].

\subsubsection{Elastase Release}

Neutrophils $\left(6 \times 10^{5}\right.$ cells $\left.\mathrm{mL}^{-1}\right)$ incubated in HBSS with MeO-Suc-Ala-Ala-Pro-Val-p-nitroanilide $(100 \mu \mathrm{M})$ and $\mathrm{Ca}^{2+}(1 \mathrm{mM})$ at $37^{\circ} \mathrm{C}$ were treated with DMSO or compound for 5 min. Neutrophils were activated with fMLF $(100 \mathrm{nM}) / \mathrm{CB}\left(0.5 \mu \mathrm{g} \mathrm{mL}{ }^{-1}\right)$ for $10 \mathrm{~min}$ [40].

\subsubsection{Statistical Analysis}

Data are displayed as the mean \pm SEM and comparisons were performed by Student's $t$-test. A probability value of 0.05 or less was considered to be significant. The software Sigma Plot (version 8.0, Systat Software, San Jose, CA, USA) was used for the statistical analysis.

\section{Conclusions}

Six new cembranoids, cherbonolides A-E (1-5) and a cembrane dimer (bischerbolide peroxide, 6), along with isosarcophine (7) were isolated from the Formosan soft coral Sarcophyton cherbonnieri. Bischerbolide peroxide (6) was discovered as the first example of cembranoid dimers possessing a peroxide group as a linking group. Compounds 1, 3 and $\mathbf{6}$ showed an anti-inflammatory activity through their inhibitory effects on the generation of superoxide anion in fMLF/CB-induced human neutrophils. Moreover, peroxide 6 was also shown to exhibit stronger activity in inhibiting the elastase release which supported its anti-inflammatory activity.

Supplementary Materials: HRESIMS, ${ }^{1} \mathrm{H},{ }^{13} \mathrm{C}$, DEPT, HMQC, COSY, HMBC and NOESY spectra of new compounds 1-6, and ${ }^{1} \mathrm{H}$ NMR spectra of (+)-sarcophytoxide and sarcophytonin after different treatments are available online at http://www.mdpi.com/1660-3397/16/8/276/s1. Figure S1: HRESIMS spectrum of 1, Figure S2: ${ }^{1} \mathrm{H}$ NMR spectrum of $\mathbf{1}$ in $\mathrm{CDCl}_{3}$, Figure S3: ${ }^{13} \mathrm{C}$ NMR spectrum of $\mathbf{1}$ in $\mathrm{CDCl}_{3}$, Figure S4: HSQC spectrum of $\mathbf{1}$ in $\mathrm{CDCl}_{3}$, Figure S5: ${ }^{1} \mathrm{H}_{-}{ }^{1} \mathrm{HCOSY}$ spectrum of $\mathbf{1}$ in $\mathrm{CDCl}_{3}$, Figure S6: $\mathrm{HMBC}$ spectrum of $\mathbf{1}$ in $\mathrm{CDCl}_{3}$, Figure S7: NOESY spectrum of $\mathbf{1}$ in $\mathrm{CDCl}_{3}$, Figure S8: HRESIMS spectrum of 2, Figure S9: ${ }^{1} \mathrm{H}$ NMR spectrum of 2 in $\mathrm{CDCl}_{3}$, Figure S10: ${ }^{13} \mathrm{C}$ NMR spectrum of 2 in $\mathrm{CDCl}_{3}$, Figure S11: HSQC spectrum of $\mathbf{2}$ in $\mathrm{CDCl}_{3}$, Figure S12: ${ }^{1} \mathrm{H}^{-1} \mathrm{HCOSY}$ spectrum of $\mathbf{2}$ in $\mathrm{CDCl}_{3}$, Figure S13: $\mathrm{HMBC}$ spectrum of $\mathbf{2}$ in $\mathrm{CDCl}_{3}$, Figure S14: NOESY spectrum of 2 in $\mathrm{CDCl}_{3}$, Figure S15: HRESIMS spectrum of 3, Figure S16: ${ }^{1} \mathrm{H}$ NMR spectrum of 3 in $\mathrm{C}_{6} \mathrm{D}_{6}$, Figure S17: ${ }^{13} \mathrm{C}$ NMR spectrum of $\mathbf{1}$ in $\mathrm{C}_{6} \mathrm{D}_{6}$, Figure S18: HSQC spectrum of $\mathbf{1}$ in $\mathrm{C}_{6} \mathrm{D}_{6}$, Figure S19: ${ }^{1} \mathrm{H}-{ }^{1} \mathrm{HCOSY}$ spectrum of 3 in $\mathrm{C}_{6} \mathrm{D}_{6}$, Figure S20: HMBC spectrum of 3 in $\mathrm{C}_{6} \mathrm{D}_{6}$, Figure S21: NOESY spectrum of 3 in $\mathrm{C}_{6} \mathrm{D}_{6}$, Figure S22: HRESIMS spectrum of 4, Figure S23: ${ }^{1} \mathrm{H}$ NMR spectrum of 4 in $\mathrm{C}_{6} \mathrm{D}_{6}$, Figure S24: ${ }^{13} \mathrm{C}$ NMR spectrum of 4 in $\mathrm{C}_{6} \mathrm{D}_{6}$, Figure S25: HSQC spectrum of 4 in $\mathrm{C}_{6} \mathrm{D}_{6}$, Figure S26: ${ }^{1} \mathrm{H}^{-1} \mathrm{HCOSY}$ spectrum of 4 in $\mathrm{C}_{6} \mathrm{D}_{6}$, Figure S27: HMBC spectrum of 4 in $\mathrm{C}_{6} \mathrm{D}_{6}$, Figure S28: NOESY spectrum of 4 in $\mathrm{C}_{6} \mathrm{D}_{6}$, Figure S29: HRESIMS spectrum of 5, Figure S30: ${ }^{1} \mathrm{H}$ NMR spectrum of 5 in $\mathrm{C}_{6} \mathrm{D}_{6}$, Figure S31: ${ }^{13} \mathrm{C}$ NMR spectrum of 5 in $\mathrm{C}_{6} \mathrm{D}_{6}$, Figure S32: HSQC spectrum of 5 in $\mathrm{C}_{6} \mathrm{D}_{6}$, Figure S33: ${ }^{1} \mathrm{H}^{1}{ }^{1} \mathrm{HCOSY}$ spectrum of 5 in $\mathrm{C}_{6} \mathrm{D}_{6}$, Figure S34: HMBC spectrum of 5 in $\mathrm{C}_{6} \mathrm{D}_{6}$, Figure S35: NOESY spectrum of 5 in $\mathrm{C}_{6} \mathrm{D}_{6}$, Figure S36: HRESIMS spectrum of 6, Figure S37: ESIMS spectrum of 6, S38: ${ }^{1} \mathrm{H}$ NMR spectrum of 6 in $\mathrm{CDCl}_{3}$, Figure S39: ${ }^{13} \mathrm{C}$ NMR spectrum of 6 in $\mathrm{CDCl}_{3}$, Figure S40: HSQC spectrum of 6 in $\mathrm{CDCl}_{3}$, Figure S41: ${ }^{1} \mathrm{H}^{-1}{ }^{1} \mathrm{HCOSY}$ spectrum of 6 in $\mathrm{CDCl}_{3}$, Figure S42: HMBC spectrum of 6 in $\mathrm{CDCl}_{3}$, Figure S43: NOESY spectrum of 6 in $\mathrm{CDCl}_{3}$, Figure S44: ${ }^{1} \mathrm{H}$ NMR spectrum of (+)-sarcophytoxide in $\mathrm{CDCl}_{3}$ before treatment with acetone and silica gel under air, Figure $545 .{ }^{1} \mathrm{H}$ NMR spectrum of $(+)$-sarcophytoxide 
in $\mathrm{CDCl}_{3}$ after treatment with acetone and silica gel under air, Figure S46. ${ }^{1} \mathrm{H}$ NMR spectrum of sarcophytonin A in $\mathrm{CDCl}_{3}$ before treatment with acetone and silica gel under air, Figure S47. ${ }^{1} \mathrm{H}$ NMR spectrum of sarcophytonin $\mathrm{A}$ in $\mathrm{CDCl}_{3}$ after treatment with acetone and silica gel under air.

Author Contributions: J.-H.S. conceived and guided the whole experiment. C.-C.P. isolated the compounds, and performed spectroscopic data measurement and analysis, and structure interpretation. C.-Y.H. and A.F.A. performed spectroscopic data analysis, confirmation of structures and preparation of the manuscript. T.-L.H. performed the anti-inflammatory assay. C.-F.D. contributed to species identification of the soft coral.

Funding: This research was funded by Ministry of Science and Technology of Taiwan (MOST102-2113-M-110-001-MY2, 104-2113-M-110-006, and 104-2811-M-110-026) and International Scientific Partnership Program (ISPP) at King Saud University, Saudi Arabia (ISPP-116).

Acknowledgments: Financial supported was mainly provided by the Ministry of Science and Technology (MOST102-2113-M-110-001-MY2, 104-2113-M-110-006, and 104-2811-M-110-026) to J.-H.S. The authors extend their appreciation to the International Scientific Partnership Program ISPP at King Saud University for funding this research work through ISPP-116.

Conflicts of Interest: The authors declare no conflict of interest.

\section{References}

1. Farag, M.A.; Fekry, M.I.; Al-Hammady, M.A.; Khalil, M.N.; El-Seedi, H.R.; Meyer, A.; Porzel, A.; Westphal, H.; Wessjohann, L.A. Cytotoxic effects of Sarcophyton sp. soft corals-Is there a correlation to their NMR fingerprints? Mar. Drugs 2017, 15, 211. [CrossRef] [PubMed]

2. Chao, C.H.; Li, W.L.; Huang, C.Y.; Ahmed, A.F.; Dai, C.F.; Wu, Y.C.; Lu, M.C.; Liaw, C.C.; Sheu, J.H. Isoprenoids from the soft coral Sarcophyton glaucum. Mar. Drugs 2017, 15, 202. [CrossRef] [PubMed]

3. Hegazy, M.E.F.; Elshamy, A.I.; Mohamed, T.A.; Hamed, A.R.; Ibrahim, M.A.A.; Ohta, S.; Pare, P.W. Cembrene diterpenoids with ether linkages from Sarcophyton ehrenbergi: An anti-proliferation and molecular-docking assessment. Mar. Drugs 2017, 15, 192. [CrossRef] [PubMed]

4. Elkhateeb, A.; El-Beih, A.A.; Gamal-Eldeen, A.M.; Alhammady, M.A.; Ohta, S.; Pare, P.W.; Hegazy, M.E.F. New terpenes from the Egyptian soft coral Sarcophyton ehrenbergi. Mar. Drugs 2014, 12, 1977-1986. [CrossRef] [PubMed]

5. Eltahawy, N.A.; Ibrahim, A.K.; Radwan, M.M.; ElSohly, M.A.; Hassanean, H.A.; Hassanean, H.A.; Ahmed, S.A. Cytotoxic cembranoids from the Red Sea soft coral, Sarcophyton auritum. Tetrahedron Lett. 2014, 55, 3984-3988. [CrossRef]

6. Lin, W.Y.; Lu, Y.; Su, J.H.; Wen, Z.H.; Dai, C.F.; Kuo, Y.H.; Sheu, J.H. Bioactive cembranoids from the dongsha atoll soft coral Sarcophyton crassocaule. Mar. Drugs 2011, 9, 994-1006. [CrossRef] [PubMed]

7. Lin, W.Y.; Su, J.H.; Lu, Y.; Wen, Z.H.; Dai, C.F.; Kuo, Y.H.; Sheu, J.H. Cytotoxic and anti-inflammatory cembranoids from the Dongsha Atoll soft coral Sarcophyton crassocaule. Bioorg. Med. Chem. 2010, 18, 1936-1941. [CrossRef] [PubMed]

8. Iwagawa, T.; Hashimoto, K.; Yokogawa, Y.; Okamura, H.; Nakatani, M.; Doe, M.; Morimoto, Y.; Takemura, K. Cytotoxic biscembranes from the soft coral Sarcophyton glaucum. J. Nat. Prod. 2009, 72, 946-949. [CrossRef] [PubMed]

9. Huang, C.Y.; Tseng, Y.J.; Chokkalingam, U.; Hwang, T.L.; Hsu, C.H.; Dai, C.F.; Sung, P.J.; Sheu, J.H. Bioactive isoprenoid-derived natural products from a Dongsha Atoll soft coral Sinularia erecta. J. Nat. Prod. 2016, 79, 1339-1346. [CrossRef] [PubMed]

10. Tseng, Y.J.; Yang, Y.C.; Wang, S.K.; Duh, C.Y. Numerosol A-D, new cembranoid diterpenes from the soft coral Sinularia numerosa. Mar. Drugs 2014, 12, 3371-3380. [CrossRef] [PubMed]

11. Lillsunde, K.E.; Festa, C.; Adel, H.; De Marino, S.; Lombardi, V.; Tilvi, S.; Nawrot, D.A.; Zampella, A.; D'Souza, L.; D'Auria, M.V.; et al. Bioactive cembrane derivatives from the Indian Ocean soft coral, Sinularia kavarattiensis. Mar. Drugs 2014, 12, 4045-4068. [CrossRef] [PubMed]

12. Li, G.; Zhang, Y.; Deng, Z.; van Ofwegen, L.; Proksch, P.; Lin, W. Cytotoxic cembranoid diterpenes from a soft coral Sinularia gibberosa. J. Nat. Prod. 2005, 68, 649-652. [CrossRef] [PubMed]

13. Cheng, S.Y.; Wen, Z.H.; Wang, S.K.; Chiou, S.F.; Hsu, C.H.; Dai, C.F.; Chiang, M.Y.; Duh, C.Y. Unprecedented hemiketal cembranolides with anti-inflammatory activity from the soft coral Lobophytum durum. J. Nat. Prod. 2009, 72, 152-155. [CrossRef] [PubMed] 
14. Chao, C.H.; Wen, Z.H.; Wu, Y.C.; Yeh, H.C.; Sheu, J.H. Cytotoxic and anti-inflammatory cembranoids from the soft coral Lobophytum crassum. J. Nat. Prod. 2008, 71, 1819-1824. [CrossRef] [PubMed]

15. Lai, K.H.; You, W.J.; Lin, C.C.; El-Shazly, M.; Liao, Z.J.; Su, J.H. Anti-Inflammatory cembranoids from the soft coral Lobophytum crassum. Mar. Drugs 2017, 15, 327. [CrossRef] [PubMed]

16. Lin, K.H.; Tseng, Y.J.; Chen, B.W.; Hwang, T.L.; Chen, H.Y.; Dai, C.F.; Sheu, J.H. Tortuosenes A and B, new diterpenoid metabolites from the Formosan soft coral Sarcophyton tortuosum. Org. Lett. 2014, 16, 1314-1317. [CrossRef] [PubMed]

17. Chao, C.H.; Wu, C.Y.; Huang, C.Y.; Wang, H.C.; Dai, C.F.; Wu, Y.C.; Sheu, J.H. Cubitanoids and cembranoids from the soft coral Sinularia nanolobata. Mar. Drugs 2016, 14, 150. [CrossRef] [PubMed]

18. Chen, B.W.; Chao, C.H.; Su, J.H.; Huang, C.Y.; Dai, C.F.; Wen, Z.H.; Sheu, J.H. A novel symmetric sulfur-containing biscembranoid from the formosan soft coral Sinularia flexibilis. Tetrahedron Lett 2010, 51, 764-766. [CrossRef]

19. Huang, C.Y.; Sung, P.J.; Uvarani, C.; Su, J.H.; Lu, M.C.; Hwang, T.L.; Dai, C.F.; Wu, S.L.; Sheu, J.H. Glaucumolides A and B, biscembranoids with new structural type from a cultured soft coral Sarcophyton glaucum. Sci. Rep. 2015, 5, 15624. [CrossRef] [PubMed]

20. Jia, R.; Kurtan, T.; Mandi, A.; Yan, X.H.; Zhang, W.; Guo, Y.W. Biscembranoids formed from an alpha, beta-unsaturated gamma-lactone ring as a dienophile: Structure revision and establishment of their absolute configurations using theoretical calculations of electronic circular dichroism spectra. J. Org. Chem. 2013, 78, 3113-3119. [CrossRef] [PubMed]

21. Kusumi, T.; Igari, M.; Ishitsuka, M.O.; Ichikawa, A.; Itezono, Y.; Nakayama, N.; Kakisawa, H. A Novel chlorinated biscembranoid from the marine soft coral Sarcophyton glaucum. J. Org. Chem. 1990, 55, 6286-6289. [CrossRef]

22. Tseng, Y.J.; Ahmed, A.F.; Dai, C.F.; Chiang, M.Y.; Sheu, J.H. Sinulochmodins A-C, three novel terpenoids from the soft coral Sinularia lochmodes. Org. Lett. 2005, 7, 3813-3816. [CrossRef] [PubMed]

23. Li, Y.; Pattenden, G. Biomimetic syntheses of ineleganolide and sinulochmodin C from 5-episinuleptolide via sequences of transannular Michael reactions. Tetrahedron 2011, 67, 10045-10052. [CrossRef]

24. Kusumi, T.; Yamada, K.; Ishitsuka, M.O.; Fujita, Y.; Kakisawa, H. New cembranoids from the Okinawan soft coral Sinularia mayi. Chem. Lett. 1990, 19, 1315-1318. [CrossRef]

25. Uchio, Y.; Eguchi, S.; Kuramoto, J.; Nakayama, M.; Hase, T. Denticulatolide, an ichthyotoxic peroxide-containing cembranolide from the soft coral Lobophytum denticulatum. Tetrahedron Lett. 1985, 26, 4487-4490. [CrossRef]

26. Hegazy, M.E.; Gamal Eldeen, A.M.; Shahat, A.A.; Abdel-Latif, F.F.; Mohamed, T.A.; Whittlesey, B.R.; Pare, P.W. Bioactive hydroperoxyl cembranoids from the Red Sea soft coral Sarcophyton glaucum. Mar. Drugs 2012, 10, 209-222. [CrossRef] [PubMed]

27. Casteel, D.A. Peroxy natural products. Nat. Prod. Rep. 1992, 9, 289-312. [CrossRef] [PubMed]

28. Liang, L.F.; Chen, W.T.; Li, X.W.; Wang, H.Y.; Guo, Y.W. New bicyclic cembranoids from the South China Sea soft coral Sarcophyton trocheliophorum. Sci. Rep. 2017, 7, 46584. [CrossRef] [PubMed]

29. Zhao, M.; Yin, J.; Jiang, W.; Ma, M.; Lei, X.; Xiang, Z.; Dong, J.; Huang, K.; Yan, P. Cytotoxic and antibacterial cembranoids from a South China Sea soft coral, Lobophytum sp. Mar. Drugs 2013, 11, 1162-1172. [CrossRef] [PubMed]

30. Kalinowski, H.O.; Berger, S.; Braun, S. Carbon-13 NMR Spectroscopy; John Wiley \& Sons: Chichester, UK, 1988.

31. Dale, J.A.; Mosher, H.S. Nuclear magnetic resonance enantiomer regents. Configurational correlations via nuclear magnetic resonance chemical shifts of diastereomeric mandelate, O-methylmandelate, and alpha-methoxy-alpha-trifluoromethylphenylacetate (MTPA) esters. J. Am. Chem. Soc. 1973, 95, 512-519. [CrossRef]

32. Ohtani, I.; Kusumi, T.; Kashman, Y.; Kakisawa, H. High-Field FT NMR application of Mosher's method. The absolute configurations of marine terpenoids. J. Am. Chem. Soc. 1991, 113, 4092-4096. [CrossRef]

33. Duh, C.Y.; Chia, M.C.; Wang, S.K.; Chen, H.J.; El-Gamal, A.A.; Dai, C.F. Cytotoxic dolabellane diterpenes from the Formosan soft coral Clavularia inflata. J. Nat. Prod. 2001, 64, 1028-1031. [CrossRef] [PubMed]

34. Corminboeuf, O.; Overman, L.E.; Pennington, L.D. Total synthesis of the reputed structure of alcyonin and reassignment of its structure. Org. Lett. 2003, 5, 1543-1546. [CrossRef] [PubMed] 
35. Chen, S.P.; Chen, B.W.; Dai, C.F.; Sung, P.J.; Wu, Y.C.; Sheu, J.H. Sarcophyton F and G new dihydrofuranocembranoids from a Donsha atoll soft coral Sarcophyton sp. Bull. Chem. Soc. Jpn. 2012, 85, 920-922. [CrossRef]

36. Bowden, B.F.; Coll, J.C.; Heaton, A.; Konig, G.; Bruck, M.A.; Cramer, R.E.; Klein, D.M.; Scheuer, P.J. The structure of four isometric dihydrofuran-containing cembranoid diterpenes from several species of soft corals. J. Nat. Prod. 1987, 50, 650-659. [CrossRef]

37. Bowden, B.F.; Coll, J.C. Studies of Australian soft corals. XLV. Epoxidation reaction of cembranoid diterpenes: Stereochemical outcomes. Heterocycles 1989, 28, 669-672. [CrossRef]

38. Kobayashi, M.; Hirase, T. Marine terpenes and terpenoids. XI. Structures of new dihydrofuranocembranoids isolated from a Sarcophyton sp. soft coral of Okinawa. Chem. Pharm. Bull. 1990, 38, 2442-2445. [CrossRef]

39. Mantovani, A.; Cassatella, M.A.; Costantini, C.; Jaillon, S. Neutrophils in the activation and regulation of innate and adaptive immunity. Nat. Rev. Immunol. 2011, 11, 519-531. [CrossRef] [PubMed]

40. Yang, S.C.; Chung, P.J.; Ho, C.M.; Kuo, C.Y.; Hung, M.F.; Huang, Y.T.; Chang, W.Y.; Chang, Y.W.; Chan, K.H.; Hwang, T.L. Propofol inhibits superoxide production, elastase release, and chemotaxis in formyl peptide-activated human neutrophils by blocking formyl peptide receptor 1. J. Immunol. 2013, 190, 6511-6519. [CrossRef] [PubMed]

41. Hwang, T.L.; Li, G.L.; Lan, Y.H.; Chia, Y.C.; Hsieh, P.W.; Wu, Y.H.; Wu, Y.C. Potent inhibition of superoxide anion production in activated human neutrophils by isopedicin, a bioactive component of the Chinese medicinal herb Fissistigma oldhamii. Free. Radic. Biol. Med. 2009, 46, 520-528. [CrossRef] [PubMed]

42. Hwang, T.L.; Su, Y.C.; Chang, H.L.; Leu, Y.L.; Chung, P.J.; Kuo, L.M.; Chang, Y.J. Suppression of superoxide anion and elastase release by C18 unsaturated fatty acids in human neutrophils. J. Lipid Res. 2009, 50, 1395-1408. [CrossRef] [PubMed]

43. Tu, Y. The discovery of artemisinin (qinghaosu) and gifts from Chinese medicine. Nat. Med. 2011, 17, 1217-1220. [CrossRef] [PubMed]

44. Kubo, M.; Minami, H.; Hayashi, E.; Kodama, M.; Kawazu, K.; Fukuyama, Y. Neovibsanin C, a macrocyclic peroxide-containing neovibsane-type diterpene from Viburnum awabuki. Tetrahedron Lett. 1999, 40, 6261-6265. [CrossRef]

45. Kamchonwongpaisan, S.; Nilanonta, C.; Tarnchompoo, B.; Thebtaranonth, C.; Thebtaranonth, Y.; Yuthavong, Y.; Kongsaeree, P.; Clardy, J. An antimalarial peroxide from Amomum krervanh Pierre. Tetrahedron Lett. 1995, 36, 1821-1824. [CrossRef]

46. Higgs, M.D.; Faulkner, D.J. Plakortin, an antibiotic from Plakortis halichondrioides. J. Org. Chem. 1978, 34, 3454-3457. [CrossRef]

47. Wells, R.J. A novel peroxyketal from a sponge. Tetrahedron Lett. 1976, 17, 2637-2638. [CrossRef]

48. Bu, M.; Yang, B.B.; Hu, L. Natural endoperoxides as drug lead compounds. Curr. Med. Chem. 2016, 23, $383-405$. [CrossRef] [PubMed]

49. Yu, H.P.; Hsieh, P.W.; Chang, Y.J.; Chung, P.J.; Kuo, L.M.; Hwang, T.L. 2-(2-Fluorobenzamido)benzoate ethyl ester (EFB-1) inhibits superoxide production by human neutrophils and attenuates hemorrhagic shock-induced organ dysfunction in rats. Free. Radic. Biol. Med. 2011, 50, 1737-1748. [CrossRef] [PubMed]

(C) 2018 by the authors. Licensee MDPI, Basel, Switzerland. This article is an open access article distributed under the terms and conditions of the Creative Commons Attribution (CC BY) license (http:// creativecommons.org/licenses/by/4.0/). 